\title{
RETHINKING U.S. SECURITIES LAWS IN THE SHADOW OF INTERNATIONAL REGULATORY COMPETITION
}

\author{
James D. Cox* \\ I \\ INTRODUCTION
}

The world we live in is a much smaller one than we faced twenty, ten, or even five years ago. Consequently, no issue of securities regulation today can be examined without considering its extraterritorial effects. This article offers a unique perspective on the concerns posed by the internationalization of our securities markets. Rather than considering how the securities laws of the United States impact international securities transactions, the traditional focus of commentators, my purpose is to develop a set of principles that can guide U.S. policymakers in reaching agreement with other nations on the minimum content of all nations' securities laws. I also suggest approaches for bringing about a wholesale revolution in domestic securities laws because, in the wake of international regulatory competition, dramatic and sweeping changes in the content of U.S. securities laws are long overdue and most certainly will occur. I will support this position with data that demonstrate that U.S. issuers and markets are disadvantaged by the greater regulatory demands U.S. securities laws impose as compared with the relatively light regulation foreign governments impose on their issuers and markets.

The boldness of my thesis is that it is both inappropriate and unnecessary to disaggregate international and domestic transactions in the formulation of regulatory regimes. To the observers of recent regulatory developments at the Securities and Exchange Commission ("SEC"), my thesis is not simply radical, but borders on heresy. The traditional and well-accepted response to internationalization has been the crafting of selective accommodations for international transactions, not changes in the domestic securities laws. Moreover, because my thesis carries a distinct deregulatory message, it surely will meet with skepticism from those who resist any sunsetting of disclosure or enforcement efforts. This certain reaction will be based on the fear that any

Copyright $\odot 1992$ by Law and Contemporary Problems
Professor of Law, Duke University School of Law.

The author expresses his appreciation for the comments he received from Lynn Stout, Patrick J. Daugherty, and the participants in the conference convened at Duke University in connection with this symposium as well as the research assistance of John D. Gardiner and Heather Stone. Parts II and III of this article are extensions of an earlier article, Regulatory Competition in Securities Markets: An Approach for Reconciling Japanese and American Disclosure Philosophies, Hastings Intl \& Comp L Rev (forthcoming 1992). 
retreat from domestic regulation necessarily abandons the protection of U.S. investors. As will be seen, such fear is misplaced.

II

\section{Financial Theory and Competitive Markets}

It is a debatable proposition whether-even if we lived in a perfect world in which consensus on any aspect of securities regulation was possible among developed nations-harmonization of securities regulation is a desirable goal. The standard argument ${ }^{1}$ favoring diversity is that it fosters experimentation and innovation using differing regulatory approaches. The approaches that prove to be efficient regulatory devices can lead the way for other nations to follow. Understanding efficiency begins with a recognition that differing regulatory approaches can be expected to embody differing costs and benefits for investors and those regulated. Yet the trade-offs between investors and the regulated is not a zero sum game; gains bestowed on one group diverge in most instances from the costs they visit on others. For example, some regulatory approaches may impose greater overall costs on issuers than the collective benefits they confer on investors by shielding them from fraudulent or improvident investment proposals. Similarly, the savings issuers enjoy because of weak disclosure demands may be dwarfed by the expenditures investors must incur to obtain the information through their own efforts. Thus, because there are differing regulatory approaches across nations, one can expect not only that the quality of regulation varies from nation to nation, but that many countries will learn from and improve upon the experiences of others and, over time, the quality of regulation for nations will generally improve.

According to the proponents of diversity, a second benefit of diversity in regulation is regulatory competition. Indeed, regulatory competition is the natural product of diversity. A beneficial effect of such competition is its potential to curb excessive laxity or rigor in any nation's securities laws. In a sense, sister state regulators provide a market force that stands ready to discipline any regulator tempted to embrace too little or too much regulation. Those with too lax a regulatory scheme will be seen as a modern day Barbary Coast, and investors will be most unwilling to launch their investment in a vessel that will pass too close to its shores. ${ }^{2}$ As securities offers and trades steer past the lax regulatory shores of that state, pressure will build for the

1. See, for example, Joseph A. Grundfest, Internationalization of the World's Securities Markets: Economic Causes and Regulatory Consequences, 4 J Financial Serv Res 349, 372-73 (1990). "Harmony" may also include setting a minimum level of regulation as is done within the European Community. See Manning Gilbert Warren III, Global Harmonization of Securities Laws: The Achievements of the European Communities, 31 Harv Intl L J 185 (1990).

2. Switzerland is a good example of a nation whose market has recently tried to improve its overall attractiveness to foreign traders of the companies whose shares are listed on its exchange. In Switzerland, as in many other countries, issuers have pressured the exchanges to improve disclosure requirements and reduce barriers to international trading. Michael R. Sesit, Once Icy Stock Market Warms to Foreigners, Wall St J Cl col 2-4 (Oct 15, 1991). 
country to bring its regulations closer to the mainstream of industrialized countries. Similarly, the country whose regulatory zeal knows no limits can expect its protection to be avoided by those who determine that the costs of compliance outstrip its benefits. Once again, this can be expected to dampen some of the regulatory zeal that otherwise will lead to disaffection.

Contemporary commentators who express comfort with regulatory diversity follow too simple a path. Their analysis fails to identify the areas in which regulatory uniformity and rigor are necessary to assure the competitive regulatory equilibrium which they believe fosters productive experimentation, innovation, and competition. Before chanting that diversity is beautiful, one need recognize that diversity can be both a blessing and a curse, depending upon the particular regulatory issue. Modern financial theory provides a convenient model by which to examine why this is so and also to assist in defining the types of disclosure issues for which diversity of regulation is not appropriate.

Presently, U.S. securities laws require more finely-tuned disclosures by companies competing for investor attention in U.S. securities markets than do any foreign laws (such as Britain's). Such differences as exist between the United States and any other country do not necessarily mean one country's disclosure requirements are either unworthy or socially wasteful. Investors considering investing in two competing markets will not be neutral to the otherwise equal risks and returns posed by the investments if they recognize that the incidence of fraud, manipulation, and unfairness is significantly lower in one market than another because of the differences in the two countries' securities laws. ${ }^{3}$ Ex ante, the investor will discount the price of the security in each market by the combined value of the average likelihood and magnitude of the feared misconduct posed by all securities traded on that exchange. Hence, the securities traded on the market that enjoys an overall lower likelihood of abusive practices will ex ante trade at prices slightly higher than they would in a less regulated market. ${ }^{4}$

Because transborder investing can occur easily, U.S. citizens can invest abroad in foreign issuers, but only with a healthy respect that those issuers operate on much less rigorous regulatory footing than do U.S.-based issuers. Under the traditional "dominance principle" of selecting investments, U.S. investors who opt for a foreign issuer do so because of a larger return,

3. There is abundant evidence that arbitrage activity exists across international markets, causing the prices of securities to reflect the effects of governmental policies. See, for example, Mustafa N. Gultekin, N. Bulent Gultekin \& Alessandro Penati, Capital Controls and International Capital Market Segmentation: The Evidence from the Japanese and American Stock Markets, $44 \mathrm{~J}$ Finance 849 (1989).

4. Linkages among the exchanges, whereby securities are traded on more than one international exchange, exacerbate the problems with this model. The linkage of exchanges poses troubling jurisdictional disputes, particularly if there is no agreement on the necessity or degree of surveillance, oversight, and proscription of conduct. Linkages can also facilitate arbitrage trading for individual, linked stocks and therefore cannot be expected to override the impact of greater risks of a foreign market's looser regulation of its markets. On the subject of linkages of international exchanges, see generally Charles C. Cox \& Douglas C. Michael, The Market for Markets: Development of International Securities and Commodities Trading, 36 Cath U L Rev 833 (1987). 
assuming each investment is of the same risk classification. Even if the foreign issuer poses more risk, the U.S. investor may still choose it because it also carries a higher expected return than the less risky U.S. issuer, and, more particularly, a sufficient increase in return over the U.S.-traded security to compensate adequately for the additional riskiness. Similarly, issuers are not bound to raise capital in their home state and will raise capital abroad when the overall cost of capital, including all transaction costs, ${ }^{5}$ such as those imposed by the applicable securities laws, is lower. Where the level of disclosure differs between two markets, as occurs between, for example, the New York Stock Exchange and the Tokyo Stock Exchange, the securities traded on the Tokyo Stock Exchange will on average be seen as riskier than those listed on the New York Stock Exchange.

From this perspective, it can reasonably be hypothesized that if the additional disclosure requirements for U.S.-listed securities were in true equilibrium such that the marginal cost of the additional disclosure did not exceed the marginal benefit, investors and issuers would be neutral in choosing whether to transact in New York or London. Issuers may as frequently prefer to offer their shares in the United States, even though this entails greater disclosure-related costs, because the securities can be sold there at a higher price. On the other hand, an issuer may choose to avoid the more demanding U.S. disclosure requirements by limiting its offer to foreign markets. If an issuer does so, however, it must expect to receive a lesser amount for its securities. Under such an equilibrium, the additional risk of transactions in the less demanding disclosure state results in a greater discount ex ante of the security's price, the amount of that discount being the total of all the various losses investors endure-losses that could have been avoided by additional disclosure-averaged across all the securities in that market. ${ }^{6}$

If we move beyond theory, we can find additional mileposts on the path toward internationalization of disclosure practices. Consider the responses of issuers and investors to diverse disclosure standards. Professors Choi and Levich, in their survey of institutional investors and corporate issuers, found that a variety of strategies were embraced to meet the challenge of differing reporting standards. ${ }^{7}$ For example, some of the institutions surveyed

5. One reason most U.S. firms do not embrace a listing on a foreign exchange is that the costs of securing a foreign listing are not trivial, and the concomitant benefits are frequently difficult to measure. See generally Robert F. Grondine, Access To Capital Markets: Do Costs Outweigh Benefts for Foreign Listers?, On TSE, East Asian Exec Rep 9 (1989).

6. This theory builds on the model first suggested in George A. Akerlof, The Market for "Lemons": Quality Uncertainty and the Market Mechanism, 84 Q J Econ 488 (1970). The resulting hierarchy among markets is described in A. Michael Spence, Market Signaling: Informational Transfer in Hiring and Related Screening Processes (Harvard U Press, 1974), which also describes how many firms may wish to signal greater reliability than the average market participant, perhaps by engaging in disclosures beyond those mandated by the market and also having such disclosures certified by outside accountants. Id at 92-97. See Ross L. Watts \& Jerold L. Zimmerman, Agency Problems, Auditors, and the Theory of the Firm: Some Evidence, 26 J L \& Econ 613 (1983).

7. Frederick D.S. Choi \& Richard M. Levich, The Capital Market Effects of International Accounting Diversity (Dow Jones-Irwin, 1990). 
circumvented the disquiet over a country's overall weak disclosure standards by basing investment choices on methods of analysis that did not depend on accounting-based factors. ${ }^{8}$ Choi and Levich report that in spite of the availability of alternative methods of evaluation, about half of those surveyed complained that the lack of comparability between issuers posed a serious problem in their investment decisions. ${ }^{9}$ Among the disclosure items posing the greatest difficulty were segmental information, methods of asset valuation, foreign operations disclosures, frequency and completeness of interim information, description of capital expenditures, hidden reserves, and offbalance sheet items. ${ }^{10}$ Clearly, short of uniform reporting standards, an objective unlikely ever to be obtained, users could benefit greatly from internationally recognized reporting standards that permit them to reconstruct a foreign company's financial statement so it could be compared with that of a company making disclosures under a more highly regulated jurisdiction. Professors Choi and Levich report that because of similar reporting standards, such comparisons can more easily be made between the United States and the United Kingdom, while comparisons are most troublesome for Germany, Japan, and Switzerland. ${ }^{11}$

From the issuers' point of view, nonuniformity poses less of a problem for raising capital because of the element of choice. North American issuers find their capital-raising decisions are not affected greatly by the difference in foreign accounting standards because their customary U.S.-based disclosures can be used when raising funds in foreign markets or seeking listings abroad. ${ }^{12}$ On the other hand, several foreign companies who do not enjoy such reciprocity report that diversity in accounting requirements causes them to avoid listing their shares in the United States. ${ }^{13}$ They further report that if they raise capital in the United States, they do so through private placement methods that avoid U.S. disclosure standards. ${ }^{14}$ This group of firms is most likely to raise capital in non-U.S. markets. Interestingly, the firms in this group also report that they still enjoy access to low-cost capital. ${ }^{15}$ Even those who reported paying more, preferred paying more to disclosing certain items they viewed as proprietary information. ${ }^{16}$

The above data offer a crisp image of the conflicting needs of investors and issuers. The users of financial information can always be expected to embrace the view that the more financial disclosure mandated, the better, especially if the disclosure costs are borne by another. To be sure, we are reminded that but for mandatory disclosure rules, users of financial information would over-

8. One way in which companies achieve this goal is by emphasizing the discounted value of dividends-an approach that does not depend on the companies' disclosures. Id at 47.

9. Id at 44 .

10. Id.

11. Id at 43 .

12. Id at 57.

13. Id at 58 .

14. Id.

15. Id.

16. Id. 
invest in research. Mandatory disclosure rules, therefore, are an efficient response. ${ }^{17}$ But as demonstrated by the above report on the behavior of many issuers, the internationalization of securities markets permits an easy escape from the unreasonable information demands of investors. Many issuers find it to be in their interest to avoid listing their shares in the United States, thus avoiding its demanding disclosure requirements; ${ }^{18}$ they enter U.S. capital markets, if at all, through the private placement mechanisms for the same reason. Not to be overlooked are the asymmetries of this freedom: U.S. investors do not have unrestrained freedom to purchase securities abroad. Their participation in securities transactions, whether participating in public offerings or simply trading in equities listed on a foreign exchange, can cause the issuers to fall within the U.S. securities laws. ${ }^{19}$

In sum, if a true equilibrium disclosure condition existed across all nations, investors would demand higher returns to invest in the lowerdisclosure nation than in the higher-disclosure nation. Consequently, issuers who raise capital in a lower-disclosure nation must be prepared to receive less for their security or to engage in nontrivial costs to signal that their security offers less risk than that of the average security so offered.

However, the world is not the perfect model relied upon by economists. There is a need for real can openers, not convenient assumptions. ${ }^{20}$ In the world as we know it, the hand of government regulation is very much needed, for it fosters, even nurtures, competition. This indeed should be seen as the mission of securities laws. To see why this is so, consider the recent experiences in unregulated competition among certain domestic markets over the issue of dual class common stock. The issue of regulation arose because of pressure on the New York Stock Exchange ("NYSE") to permit the listing of common shares for public shareholders when the issuer already had a second class of common stock outstanding with enhanced or "super" voting rights. The NYSE had historically barred dual class common stock, ${ }^{21}$ whereas the National Association of Securities Dealers Stock Quotation system

17. See John C. Coffee, Jr., Market Failure and the Economic Case for a Mandatory Disclosure System, 70 Va L Rev 717, 717-23 (1984).

18. In this regard, consider the pending request to the SEC by the NYSE that competition for foreign issuers be allowed to list their shares on the NYSE without subjecting themselves to the United States' generally accepted accounting standards. 24 Sec Reg \& L Rep (BNA) $645-46$ (May 1, 1992). See also Gregg A. Jarrell, SEC Crimps Big Board's Future, Wall St J A 10 col 3-6 (June 19, 1992).

19. For example, Regulation $S$, the "safe harbor" from registration under the Securities Act for foreign offerings, is not available if U.S. residents purchase the distributed securities within any restricted period. Under Rule 903(a) the offer must be an "offshore transaction," which is defined in Rule 902(i) not to include purchases by a U.S. resident. Also, resales to a U.S. resident by a foreign national who purchased abroad under Rule 904 destroys the safe harbor if it occurs within any proscribed restricted period. See, for example, Rules 903(c)(2)(iv), (3)(ii), (3)(iii). Furthermore, the continuous reporting requirements of the Exchange Act can be triggered if a foreign issuer's equity security is held of record by 300 or more resident U.S. shareholders. See Exchange Act Rule 12-g32(a), 17 CFR \& 240.12g3-2(a) (1992).

20. The reference here is to the story of how an economist, a minister, and a physicist each answered the question how he would open cans of food if stranded on an isolated island without a can opener. The economist's answer: "Assume you have a can opener

21. New York Stock Exchange Listed Company Manual Rule 313.000(A)-(C) (1990). 
("NASDAQ") placed no limitation on multiple classes of voting common stock. The American Stock Exchange ("AMEX") stationed itself between these two positions, permitting the listing of multiple classes of common stock if the inferior class is permitted to elect at least twenty-five percent of the board of directors. ${ }^{22}$ The hierarchy among the exchanges over this issue has been convincingly explained in terms of the stronger commitment of NYSElisted companies' managers to bond themselves to act more efficiently to serve their stockholders' interests. ${ }^{23}$ The strength of that bond would be eroded if managers could easily embrace dual classes of stock such that they could not be displaced through a hostile takeover. In return for bonding themselves to the higher governance standards of the NYSE, the companies enjoyed a lower cost of capital, greater liquidity for the individual company's shares, and a variety of pecuniary and nonpecuniary gains derived from the enhanced reputation of being listed on the NYSE. The combination of a pervasive threat of takeovers in the 1980s and the emergence of NASDAQ as a highly liquid and efficient market caused managers to reevaluate the costs and benefits of being listed on the NYSE. Simply put, given the choice between their firms reaping slightly lower capital costs and their own greater job security, managers opted for steady paychecks and began to leave the NYSE. Faced with defections from its elite trading posts, the NYSE pleaded for Congress or the SEC to act to prevent managers from acting opportunistically vis-à-vis their public shareholders. ${ }^{24}$

The message behind the dual class voting scenario is that the rewards firms garner by listing their shares on the NYSE may be overwhelmed by the costs their managers incur by continuing to list the company's stock there. The result of separation of ownership from management is that managers predictably choose their conduct in a way that does not necessarily assure that the firm's interests will also be maximized. This leads to the next observation: competition among the exchanges is far more likely to result in a "race to the bottom," in which the exchanges are able to develop clienteles based upon purely managerial, rather than corporate, interests. ${ }^{25}$ Restated from an

22. American Stock Exchange Company Guide (CCH) \ 10,022 (1992).

23. See Jeffrey N. Gordon, Ties that Bond: Dual Class Common Stock and the Problem of Shareholder Choice, 76 Cal L Rev 1 (1988).

24. The SEC's response was to promulgate Rule $19 \mathrm{c}-4$, which required the various exchanges and the NASD to include among their listing requirements standards barring issuers who had taken action that would have the effect of "nullifying, restricting or disparately reducing the per share voting rights of common stock of such issuer registered under section 12 [of the Exchange Act]." Voting Rights Listing Standards, Exchange Act Rel No 25891, Fed Secur L Rptr (CCH) 95,291 (1990). The rule was invalidated, however, in Business Roundiable v Securities and Exchange Commission, 905 F2d 406 (DC Cir 1990).

25. Professor Fischel takes issue with the "race to the bottom" thesis, arguing that shareholders and investors, who enjoy an infinite number of investment opportunities, will not trust their money with managers who seek havens where shareholders and investors can be exploited. Daniel R. Fischel, Organized Exchanges and the Regulation of Dual Class Common Stock, 54 U Chi L Rev 119 (1987). Professor Fischel's argument is vulnerable on the ground that shareholders are presented a distorted choice on such questions. See Lucian A. Bebchuk, Limiling Contractual Freedom in Corporate Law: The Desirable Constraints on Charter Amendments, 102 Harv L Rev 1820, 1836-40 (1989). For example, investors may well view the corporation's decision to raise capital in Britain as driven by the desire to 
international perspective, inter-country regulatory competition is likely to result in a race to the bottom where among the many items subject to differing regulatory approaches are those that further solely the self-interest of managers. ${ }^{26}$ What disrupted the efficient differences among the NYSE, AMEX, and NASDAQ was not the presence or absence of a specialist system, the question of whether pricing was more fragmented in the dispersed NASDAQ market versus the trading posts of the two leading domestic exchanges, or the rapidity with which orders are executed. Rather, the disruption was that NASDAQ, and to a lesser extent AMEX, allowed purely managerial, as opposed to corporate, interests to be served by listing multiples classes of common stock there. Thus, the varying costs of capital due to the relative efficiency and fairness of the competing markets played a diminished role in each company's listing decision. The possibility for managerial opportunism that existed under the NASDAQ and AMEX listing requirements assured there could be no competitive equilibrium among the markets.

Because of the phenomenon described above, it is important that the Commission and other regulators-though they may differ on how to regulate their respective markets-undertake a commitment that their country's securities laws will not permit purely private decisions to overwhelm a company's capital decisions. The goal is to promote inter-market/internation competition on matters that benefit the issuer's interest. To assure a full competitive equilibrium among markets, such that those markets with greater regulation reflect lower costs of capital than those that are less heavily regulated, the individual firm's decision where to list the company's shares for trading and where to undertake a public offering should be guided by the regulatory impact on the company, and not exclusively by the managers' utility function. That is, each nation's disclosure rules should disallow managerial choices to transfer wealth from the issuer to the manager. To permit such a transaction introduces an undesirable effect, not only on the content of regulation, but also on competitive regulation among nations. ${ }^{27}$

minimize issuing costs and not management's desire to avoid disclosure of its compensation arrangement or to trade in a market where the managers' insider trading activities are less likely to be detected or prosecuted.

26. Professor Charny has similarly raised the specter of a "race to the bottom" within the EC member states on a range of corporate and securities issues. David Charny, Competition among Jurisdictions in Formulating Corporate Law Rules: An American Perspective on the "Race to the Bottom" in the European Communities, 32 Harv Intl L J 423 (1991). He also emphasizes the potential for managerial opportunism to overwhelm corporate and stockholder interests in choosing the venue for incorporation or securities transactions. Nevertheless, Professor Charny's analysis stops short of normative suggestions that can guide EC member states in agreeing upon the minimum content of all nations' corporate and securities laws. Indeed, it is just such a process, occurring through the window of mutual recognition, that is the mechanism for avoiding a dysfunctional race to the bottom with the EC. See E. Waide Warner, "Mutual Recognition" and Cross-Border Financial Services in the European Community, 55 L \& Contemp Probs 7 (Autumn 1992). See also Warren, 31 Harv Intl L J at 185 (cited in note 1 ).

27. Compare Lucian A. Bebchuk, Federalism and the Corporation: The Desirable Limits on State Competition in Corporate Law, 105 Harv L Rev 1435 (1992) (identifying the shortcomings of state 


\section{III}

\section{Managerial Opportunism and the Content of Securities Laws}

Of paramount importance in formulating a position regarding international agreements on the content of securities laws is what can best be described as the abuse of "managerial opportunism." Not all concerns that may influence managerial choice among markets competing for a firm's offering or listing are instances of managerial opportunism. For example, an issuer may well prefer to avoid listing its security in the United States, believing that the additional disclosure regarding its future operations compromises its product marketing strategies. To advance this interest of the firm, its managers may select a capital market where a higher discount rate can be expected due to that country's weaker disclosure laws. Because such a decision is grounded on the issuer's interest, it falls outside the managerial opportunism rubric. The differences in disclosure laws should be viewed as evidence of healthy regulatory competition and not cause for the United States to charge foul on the part of the lower-disclosing country.

In contrast, management's decision not to offer an issuer's security in U.S. markets because of the requirement to disclose any earlier self-dealing contracts with the issuer ${ }^{28}$ would be a decision guided by managerial opportunism because the manager's desire to avoid disclosure produces no corresponding benefit to the issuer. Thus the standard for characterizing whether a disclosure item should be universal is whether that item is morethan-likely to be one whose avoidance would be motivated primarily by the private interests of the manager and not the interests of the issuer. This standard is important because only those considerations that bear on the costs and benefits to the issuer can be seen as having a legitimate role in competitive regulation. Simply stated, countries that tolerate managerial opportunism effectively cheat in this competition. Cheating countries garner rents via weak regulation at the expense of both investor protection and fair competition with their sister nations.

This section illustrates some areas of managerial opportunism and further refines the principles that can guide the United States and other nations in resolving their regulatory differences. In considering where regulating nations should direct their efforts to reduce the likelihood that the firm's cost of capital plays a secondary role to the manager's agenda, the reader should be aware that no manager is likely initially to select the country where her company will go public or even first list its securities for trading purely on concerns of managerial opportunism. Practice reflects that strong commercial interest and good financial sense support going public and obtaining an initial listing in a country where the issuer already has substantial operations. Moreover, within even medium-sized public firms, strong organizational

competition in governing corporate affairs and encouraging an expansion of the federal laws regulating corporations).

28. See, for example, Securities Act Reg S-K Item 404, 17 CFR § 229.401 (1991). 
pressures exist for some internal controls, ${ }^{29}$ irrespective of weak governmental directives on the same subject. Hence, a nation's securities laws cannot be viewed as the sole bulwark against managerial opportunism.

Nevertheless, the concern posed by international regulatory competition is not so much that the venue of initial public offerings or a firm's primary listing will be shaped by managerial opportunism; rather, the concern is that the later financing decisions of seasoned firms may give undue weight to their managers' interests when making that choice. Managers are more able to manipulate the decisions of established firms, because they already enjoy a presence in international business that makes it financially practical to consider offering their securities outside their home countries or obtaining second listings in other countries. At this level, concern for managerial opportunism runs a serious risk of deflecting the natural intermarket equilibrium that otherwise would exist. The remaining portion of Part III examines how concerns for managerial opportunism should inform the content of securities law provisions directed toward market offenses and financial disclosure.

\section{A. Market Offenses}

Market offenses are those activities undertaken for the purpose of artificially influencing a security's price or volume. This category includes such common offenses as falsifying financial reports and manipulating stock prices. The universal condemnation of these offenses reflects the simple lesson that allowing such market offenses would produce costs greatly in excess of the corresponding competitive gains over the countries whose markets regulate these offenses. Indeed, market offenses can be seen as the purest form of managerial opportunism. To allow misleading announcements permits managers to provide their own self-serving versions of their stewardships, a temptation not many managers resist. Similarly, stock price manipulation allows market professionals and others to profit not by their socially productive arbitrage activities, but by their discrete and clandestine shifts in resources among various stocks to create the false appearance of investor interest. Proscription of false announcements and manipulation, therefore, can be seen as having the desirable effect of channeling the

29. There are several possible sources for these interorganizational pressures. To the extent managerial compensation is dependent on the firm's performance, a good deal of interdependence exists among managers to avoid misbehavior that threatens their mutual benefit. Compensation is so dependent through standard bonus or option arrangements linked to distinct performance measurements or through serious evaluation by the board of directors. Neoclassical economists therefore counsel linkages between compensation and changes as a natural method to reduce agency costs. See generally Michael C. Jensen \& William H. Meckling, Theory of the Firm: Managerial Behavior, Agency Costs and Ownership Structure, $3 \mathrm{~J}$ Fin Econ 305 (1976); Note, The Executive Compensation Contract: Creating Incentives to Reduce Agency Costs, 37 Stan L Rev 1147 (1985) (authored by Geoffrey S. Rehnert). The less imminent, but by no means less feared, is the threat that a co-manager's misbehavior may lead to a wholesale displacement of the management team and their future expected salaries. Compare John C. Coffee, Shareholder Versus Managers: The Strain in the Corporate Web, 85 Mich L Rev 1, 73-80 (1986). 
energies of managers and market professionals into positive economic activities. Regulating these market offenses focuses the managers' attention on making better mousetraps and the attention of market professionals on identifying who has made better mousetraps. Without such regulation, managerial opportunism could threaten to crowd out these worthwhile activities.

The universal proscription of insider trading ${ }^{30}$ can similarly be explained as a response to grave concerns of managerial opportunism. Other than those of the "Chicago School" who continue ${ }^{31}$ to mimic Henry Manne's provocative work, ${ }^{32}$ there is wide condemnation of insider trading, not just among commentators, but also among developed capital markets. Such regulation is commonly justified out of concern for unwitting investors ${ }^{33}$ or the necessity of preserving the integrity of markets. ${ }^{34}$ Each of these rationales can more generally be seen as furthering the need to curb the incidence of managerial opportunism.

Regulation of insider trading can be viewed as a nation's response to fears of managerial opportunism in two different ways. First, a classic concern of insider trading is preserving a market's integrity or, more specifically, addressing investor concerns that they may be the victims of insider trading. To see how insider trading raises these concerns, we must consider what behavior would occur if there were a laissez-faire attitude toward insider trading. If this were so, there would be cause to fear that managers might be tempted to manipulate their company's disclosure practices to advance their own insider trading agenda. For example, newsworthy events would not be announced promptly, or at least not until the insider and others had first captured a large share of the firms' anticipated change in value through their own trading. Even if there were no significant developments that would cause a price change, managers might be tempted to create intertemporal price fluctuations through ambiguous corporate disclosures and signals; managers could then enter the market to purchase their firm's securities at what they knew to be a low price and then sell that security after a clarion announcement had increased its price by removing the earlier ambiguity and uncertainty. The ultimate seduction of a laissez-faire approach is its encouragement to manipulate the initiation or timing of real economic events to cause greater volatility in the firm's securities, thus creating an ongoing

30. An excellent review of the regulatory approaches to insider trading in other countries appears in Harvey L. Pitt \& David B. Hardison, Games Without Frontiers: Trends in the International Response to Insider Trading, 55 L \& Contemp Probs 199 (Autumn 1992).

31. See, for example, Dennis W. Carlton \& Daniel R. Fischel, The Regulation of Insider Trading, 35 Stan L Rev 857 (1983); Jonathan R. Macey, From Faimess to Contract: The New Direction of the Rules Against Insider Trading, 13 Hofstra L Rev 9 (1984).

32. Henry Manne, Insider Trading and the Stock Market (The Free Press, 1966).

33. See, for example, William K.S. Wang, Trading on Material Information on Impersonal Stock Markets: Who Is Harmed, and Who Can Sue Whom Under SEC Rule 1Ob-5?, 54 S Cal L Rev 1217, 1235-40 (1981) (insider trading induces unsuspecting investors to trade and also preempts the price they otherwise would obtain).

34. See, for example, Matter of Cady, Roberts $\mathfrak{E}$ Co., 40 SEC 907, 912 (1961). 
condition rife for insiders to capitalize on their unerodable information advantage.

So viewed, regulation of insider trading can be seen as a necessary prophylaxis to deal with abusive managerial decisionmaking; managers now enjoy great discretion on such matters as the timing and relative clarity of corporate releases, ${ }^{35}$ as well as what business opportunities the firm will pursue. Such regulation addresses the uncertainty that would otherwise exist: whether sound managerial judgment or hidden motive guided the timing and ambiguities of an announcement, the initiation or selection of a project, or the degree of overall business risk embraced. Not only does proscription of insider trading remove an incentive that can seriously corrupt managerial judgment, it also focuses regulation on more objectively verifiable behaviorwhether the manager traded while in possession of material nonpublic information.

The second way in which regulation of insider trading can be viewed as a manifestation of concern for managerial opportunism is the need to understand fully the costs and benefits of managerial talent. Elsewhere I have argued that insider trading regulation is a bare reflection of the agreement a firm's owners and managers would have entered into if they could contract efficiently. ${ }^{36}$ That public laws can be viewed as default private contractual provisions is not new to the literature of securities regulation. ${ }^{37}$ Not surprisingly, there is a good deal of debate among the commentators over precisely what the parties would have contracted for had they done so at the outset of their relationship. A superb example of the indefiniteness of this inquiry is found in Jordan v. Duff $\mathcal{E}^{2}$ Phelps, Inc., ${ }^{38}$ where Judges Easterbrook and Posner reach opposite conclusions about whether an employee-owner, who was required to sell his shares to the corporation at their book value upon leaving the firm's employ, would have negotiated $e x$ ante disclosure of particular material nonpublic information about the firm by its managers when the employee was considering changing jobs. Nevertheless, the contracting paradigm offers a useful mechanism for examining the content of legal rules, and, in the case of insider trading, it further illustrates that managerial opportunism is at the core of international regulatory concern in this area.

35. In this regard, consider how weak a corporation's obligation is with respect to correcting investors' misimpressions when the false information is not attributable to the corporation. See Elkind v Liggett $\mathfrak{G}^{2}$ Myers, Inc., 635 F2d 156, 164 (2d Cir 1980). Corporations can delay the release of material information so long as there is a business justification for nondisclosure. State Teachers Retirement Bd. $v$ Fluor Corp., 654 F2d 843 (2d Cir 1981). Furthermore, when a correction is necessary, ample time and deference are accorded the corporation to assure a fair and clear corrective announcement. See Financial Industrial Fund, Inc. v McDonnell Douglas Corp., 474 F2d 514 (10th Cir 1973).

36. James D. Cox, Insider Trading and Contracting: A Critical Response to the "Chicago School," 1986 Duke L J 628, 655-59.

37. This view is most frequently advanced in the area of corporate law, see Frank R. Easterbrook \& Daniel R. Fischel, The Economic Structure of Corporate Law 34 (1991), but it is easily portable to securities law matters. Id at 276-90.

38. 815 F2d 429 (7th Cir 1987). 
The linchpin for all contracting in the publicly traded corporation is the separation of owners and managers. The gulf that separates the two assures that managers have far greater information about the costs and benefits of their contribution to the firm. Rational investors minimally do not desire an open-ended compensation arrangement with their firms' managers. Under an open-ended compensation schedule, a manager's total compensation package bears no relationship to the firm's performance or the individual manager's contribution to that performance. Transparency, or full disclosure, is crucial to the policing of managerial behavior. Insider trading regulation promotes transparency because it eliminates the possibility that managers will supplement their visible compensation schedules with clandestine gains reaped through their advance knowledge of their firms' activities. Absent universal insider trading regulation, managers could raise capital and list shares in safe havens for insider trading. Allowing insider trading, therefore, would provide the opportunity to circumvent the most primary of all contractual understandings managers have with owners: providing fair compensation for their services.

The preceding discussion does not merely offer concrete illustrations of abuses that have earned uniform condemnation; it more importantly explains each type of market offense as a form of managerial opportunism. So explained and understood, each market offense can be linked to the international competitive model described in Part II so that the importance of addressing the incidence and possibilities of managerial opportunism gains renewed importance in the dialogue among nations on the content of their own securities laws. The next section explores the limits of managerial opportunism in the more difficult setting, the content of financial disclosure.

\section{B. Financial Disclosure}

In contrast to the nearly universal proscription of market offenses, reporting obligations vary widely among developed nations. ${ }^{39}$ In the area of financial disclosure, U.S. companies, market professionals, and regulators most loudly complain that the rest of the world's securities markets must make dramatic changes in their securities laws so that U.S. issuers and markets are not unduly disadvantaged by the more demanding U.S. disclosure standards. In these discussions, one is repeatedly reminded that the depth, detail, and frequency of U.S. disclosure requirements are unrivaled anywhere in the world. Such domestic complaints receive added force when they are joined by a chorus of foreign issuers who object to the added disclosure burdens they incur when offering or listing securities in the United States. ${ }^{40}$

In the face of these complaints, the United States has three regulatory choices. First, it could hold the line and continue its efforts to move foreign

39. See generally Scott D. Cohen, Survey of Registration and Disclosure Requirements in International Securities Markets, 9 Mich Yearbook of Intl Legal Studies 243 (1988).

40. Robert P. Austin, Regulatory Principles and the Internationalization of Securities Markets, 50 L \& Contemp Probs 221 (Summer 1987). 
disclosure standards closer to those mandated by U.S. securities laws. Second, it could selectively accommodate the special needs of foreign issuers by exempting them from domestic disclosure demands or third, it could reevaluate U.S. disclosure standards with a view toward placing U.S. companies and markets on a more competitive footing with foreign companies and markets. As will be seen in this section, as well as in Part IV, this process is delicate and need not lead to wholesale revision of the mandatory disclosure requirements.

These three regulatory choices are not mutually exclusive; they can, of course, be pursued simultaneously with respect to different disclosure items. For example, the first option could be pursued with respect to the meaning of "independence" when applied to the firm's outside accountants and, simultaneously, the SEC could discontinue line of business reporting as a required disclosure item. Nevertheless, the second option, according foreign regulators less demanding disclosure burdens than their U.S. counterparts, is clearly not a viable option. This approach has distinct political costs, for in today's political and economic environment one cannot long survive by championing a position that places domestic companies, markets, or workers at a competitive disadvantage to foreign companies, markets, or workers. This approach also makes poor regulatory sense. To embrace different disclosure obligations for companies that are competing for capital robs the process of its ultimate objective of comparability. The central objective of mandatory disclosure is to facilitate investor choice among competing investment opportunities by providing easily comparable information about each opportunity. Any disclosure policy that permits foreign issuers to satisfy U.S. disclosure standards with information that cannot easily be translated into U.S. disclosure format or content for easy comparisons conflicts with the overall purpose of mandatory disclosure.41 Determining which of the three options (realistically only the first and/or third options) to apply to a particular item requires a unifying philosophy for international disclosure. Once again, the learning obtained from Part II can help formulate the best approach for specific disclosure issues.

To illustrate, the article next examines several financial disclosure issues against the model of international markets and managerial opportunism that was developed in Part II. Specifically, the issues examined are the reporting of accounting changes, methods of reserve accounting, consolidated financial reporting, line of business reporting, and management discussion and

41. Companies that do not list their shares on an exchange or authorize their trading through NASDAQ but nonetheless have 300 or more U.S. resident stockholders can comply with the continuous disclosure requirements of the Exchange Act by filing so-called "home country information." See Exchange Act Rule 12g3-2(b), 17 CFR $\$ 240.12 \mathrm{~g} 3-2$ (b). Moreover, even foreign registrants who are not able to avail themselves of this provision are relieved of disclosing some of the information that their U.S. counterparts must disclose. For example, they are exempt from the quarterly reporting requirements and the proxy rules. See generally Harold S. Bloomenthal, $3 \mathrm{C}$ Securities and Federal Corporate Law $\S 15.13[3][b]$ (Clark Boardman, 1991 revision). 
analysis of financial reports. To add concreteness to this analysis, the specific disclosure practices of Japan and the United States are contrasted.

The common quest of managers for security and reputation can also plant the seeds for managerial opportunism, which frequently takes the form of an opportunistic use of legitimate accounting standards. The propensity to manipulate accounting methods is underscored by the well-documented prevalence of income-smoothing among managers. ${ }^{42}$ Managers have strong incentives to avoid disclosing abrupt and significant changes in revenues, costs, and earnings, particularly if changes in these items are less favorable than those of prior years. ${ }^{43}$ Hence, managers' desire to minimize intertemporal changes in revenues, costs, and earnings. This objective can be achieved by a deft use of discretion over accounting choices so as to smooth the valleys and peaks that otherwise would appear in the company's trend lines for sales, expenses, and income.

Interestingly, while empirical data supports the belief that managers of U.S. corporations engage in income smoothing, there is also abundant evidence that income smoothing does not fool the market. ${ }^{44}$ Its inability to mislead the market can be attributed to the nearly two decades-long requirement that when a material accounting change occurs, there must be disclosure of enough information to permit investors to determine what the reported results would have been had the change in estimate or principle not been made. ${ }^{45}$ Indeed, this is a prevalent feature of U.S. disclosure laws. Where more than one reporting choice is available, companies are permitted to exercise a choice, so long as enough collateral disclosure is made to enable users of financial statements to determine reported income or financial position under a different method. This feature is not so much a protection against fraud as it is a means of assuring comparability among reporting companies.

In sharp contrast to prevailing U.S. accounting practices, Japanese accounting methods are concerned with reporting the use of companies' "reserves." Reserves are common in Japanese companies and exist for such diverse purposes as retirement and severance benefits as well as to absorb the cost of extraordinary items. ${ }^{46}$ Because reserves are highly discretionary items with additions and withdrawals requiring a minimum of disclosure, they can be used to smooth reported income from year to year. Further discretion exists with respect to foreign currency translations. Multinational Japanese corporations that have a presence internationally through branches, divisions,

42. See generally James D. Cox, Financial Information, Accounting and the Law: Cases and Materials ch 7, at 443-99 (Little Brown, 1980).

43. William J. Baumol, Business Behavior, Value and Growth 101-03 (Harcourt, Brace \& World, 1967).

44. See, for example, Robert K. Eskew \& William F. Wright, An Empirical Analysis of Differential Capital Market Reactions to Extraordinary Accounting Items, 31 J Finance 651 (1976); Robert S. Kaplan \& Richard Roll, Investor Evaluation of Accounting Information: Some Empirical Evidence, $45 \mathrm{~J}$ Bus 225 (April, 1972).

45. See A.I.C.P.A. APB Opinion No 22 (1922).

46. Takeji Yamashita, Japan's Securities Markets: A Practitioner's Guide (Butterworths, 1989). 
and subsidiaries in numerous countries necessarily encounter the question of how to translate such off-shore profits and losses into yen. Whereas in the United States there is a highly stylized approach to such translation, ${ }^{47}$ in Japan there is a good deal of laxity in disclosure standards for foreign exchange translations. For example, Japanese corporations are not bound to use the currency of the country where a transaction occurs and Japanese corporations can apply different transaction rates for subsidiaries and branches. ${ }^{48}$ Overall, this freedom provides a powerful temptation and expedient mechanism for Japanese managers to affect overall results, not only by the exchange rate selected, but also by deft characterization of the off-shore entity as a branch or a subsidiary.

Quite a different potential for manipulating reported results arises in the area of consolidated accounting. For many years, the United States has fairly rigidly controlled when a parent corporation must issue consolidated financial statements. ${ }^{49}$ In broad overview, U.S. reporting standards require consolidation when a corporation directly or indirectly owns fifty percent or more of another company. Additionally, the so-called "equity method" of including another corporation's position and performance is required when twenty to fifty percent ownership exists. Japan, however, does not require ${ }^{50}$ consolidation if the subsidiary's assets, sales, and income are ten percent or less than those of the consolidated enterprise. ${ }^{51}$ Thus, Japanese reporting standards accord the parent corporation great discretion when to consolidate a subsidiary's earnings with those of the parent, providing the subsidiary, although substantially owned, is not so sizable as to trigger the ten percent standard; under U.S. reporting standards, such discretion does not exist. This has, on occasion, allowed the practice of "window dressing," whereby profits and losses can be hidden in the accounts of subsidiaries, going unreported on their affiliated companies' accounts. In this regard, consider Tomio Shida's analysis of the issue of consolidated versus unconsolidated reporting:

[I]s there always a big difference between consolidated and unconsolidated earnings in Japan? The answer is no, generally speaking. A survey comparing parentonly and consolidated earnings for the latest terms available indicates that out of more than 2,000 listed companies, the consolidated earnings of over 400 were more than 1.1 times bigger than parent-only figures, and that the consolidated earnings of $\mathbf{5 0}$ were more than two times as large ....

The Nihon Keizai Shimbun forecast the 1987 . . business performance of 802 manufacturers and non-manufacturers listed on the Tokyo, Osaka, and Nagoya stock exchanges. Consolidated net income is expected to grow an average 10.9 percent and

47. See A.I.C.P.A. APB Opinion Nos $16 \& 17$ (1970).

48. Yamashita, Japan's Security Markets at 245 (cited in note 46).

49. See note 45.

50. Even though not required, some Japanese companies have voluntarily disclosed such information, finding that the positive reaction of investors is a benefit sufficient at least to incur the extra costs of such consolidated reporting. Groups Releasing Consolidated Results: Disclosure No Longer Confined Only to Parent, Japan Econ J 36 col 1-3 (June 23, 1990); Tomio Shida, MOF Adopts Lax Rule on Disclosure, Japan Econ J 1 (Jan 19, 1991) (While some release consolidated information, most issuers are relieved the Ministry of Finance backed away from mandating such disclosure.).

51. Shida, Japan Econ J at 247 (cited in note 50). 
parent-only net income 7.1 percent, meaning that consolidated net income will be about 1.2 times larger than parent-only net income.

Since unconsolidated or parent-only estimates become available before consolidated ones, investors are most accustomed to them, and, generally, there are not many differences between the two sets of figures. Securities houses compete in being the first to provide investors with accurate unconsolidated estimates. These estimates are published in newspapers and they are convenient for investors to grasp a general trend for the year ahead. ${ }^{2}$

One can view this situation less sanguinely than Mr. Shida. Some twenty percent of the sampled firms had consolidated earnings at least ten percent greater than those reported for the parent. ${ }^{53}$ Moreover, one should consider the incentives such weak disclosure demands provide for analysts to garner inside information for their clients about a firm's likely consolidated performance. That is, an important function Japanese brokers serve is fillingin the disclosure gaps by seeking and purveying "the real" information about Japanese issuers. This information is dignified by being referred to as "analysts' forecasts," but nonetheless arises because of the lacunae within Japan's disclosure rules. The condition reflects the way in which weak disclosure rules make insider trading more likely and also leads to pricing inefficiencies because analysts' predictions, while filling a gap, can be expected to be less reliable than those provided by the firm itself. ${ }^{54}$

A different disclosure issue is illustrated by a report that in June 1989, Akai Electric Company, an audio equipment manufacturer, issued a one-page release announcing revisions to its earnings forecast for the year. The brief release announced the company expected to post a pretax recurring loss of $¥ 2.79$ billion. Virtually no information was disclosed that would have enabled investors to assess whether the unexpected drop in earnings was due to sustained competition or strategic miscalculations by management; nor did the report shed light on how long the adverse conditions were likely to continue. ${ }^{55}$

This situation should be contrasted with what occurs in the United States, where the "Management Discussion and Analysis" portion of Regulation S-K requires companies in such situations to disclose known conditions and trends that are reasonably likely to have a material effect on earnings, assets, or liabilities.56 Japan's disclosure requirements do not impose a similar

52. Id at 248-49. The survey referred to is identified by the author as Kaisha Shikiho (Company Quarterly), Toyo Keizai Shiinposha, first quarter 1988.

53. Parents are under no obligation to report their affiliates' earnings if they either own less than $50 \%$ of the affiliate or the affliate's earnings or assets are no more than $10 \%$ of the firm's assets, sales, and income. Yamashita, Japan's Securities Markets at 247.48 (cited in note 46).

54. See, for example, Bikki Jaggi, Further Evidence on the Accuracy of Management Forecasts Vis-a-Vis Analysts' Forecasts, 55 Acct Rev 96 (1980).

55. TSE's Handling of Disclosure Leaves Insiders, Public in Dark, Japan Econ J 32 (Nov 4, 1989). The report also disclosed that the company's president did selectively explain the factors contributing to the unexpected loss to the company's banks. Id.

56. Securities Act Reg S-K Item 303, 17 CFR $\S 229.303$. See generally Financial Information Rel No 36, Fed Secur L Rptr (CCH) 973,193 (1989). To be sure, the Management Discussion and Disclosure does not apply to press releases but does come into effect with the periodic disclosures mandated for reporting companies. See, for example, Form 10-Q Part 1, Item 2. 
obligation to explain or identify whether the conditions contributing to the loss are likely to continue and, if so, with what general effects. Thus, one can find in the Akai Electric illustration criticism not just of Japanese disclosure laws but also of the laws of most countries other than the United States, because they lack the detail and depth of the U.S. disclosure requirements.

A final illustration involves the reporting of line of business information. U.S. companies are required to disclose certain financial information for any product or group of products that account for at least ten percent of an enterprise's total profits. If a product meets this criterion, the company must report its revenues, profits, or losses, and the assets used for the product or group of products. ${ }^{57}$ Issuers generally have opposed segmental reporting because they believe disclosures based on specific product lines can rob the firm of potential competitive advantages. Nevertheless, the information is required by U.S. disclosure rules because of its demonstrative usefulness to investors. ${ }^{58}$ In contrast, Japan's disclosure laws do not require line of business reporting. ${ }^{59}$

As reviewed above, Japan provides weaker financial reporting rules for each of the items examined-changes in accounting method, reserve accounting, foreign currency translations, consolidated reporting, management discussion and analysis, and line of business reporting. Not all of these items, however, raise the specter of managerial opportunism. Even when this specter is raised, there is sometimes an additional consideration, identified below, that excuses compliance with an international standard for uniform minimum disclosure. For example, weaknesses in consolidated reporting, reserve accounting, and foreign currency translations enable managerial opportunism that can cause Japanese corporations to consider factors other than their stockholders' interests when deciding whether to seek a listing abroad or to undertake a global offering. Similarly, under prevailing accounting standards, Japanese managers enjoy broad discretion to smooth income through accounting changes. Such behavior impairs listing and offering decisions, and thereby poses serious questions to those concerned with fostering: regulatory diversity and competition in securities markets. Finally, the disclosure requirements in Japan and most other non-U.S. countries are much less stylized and penetrating than those that exist in the United States.

Certainly this point is underscored by the increasing disclosure demands the SEC imposes on issuers through the management discussion and analysis of each domestic issuer's basic disclosure package. Each of the Japanese disclosure weaknesses can therefore be seen as presenting fertile ground for the type of managerial opportunism that can defeat a competitive regulatory

57. See, for example, F.A.S.B. Statements Nos 14, 30.

58. See, for example, Daniel Collins, SEC Line-of-Business Reporting and Earnings Forecasts, $4 \mathrm{~J}$ Bus Res 117 (1976).

59. Yamashita, Japan's Securities Markets at 245 (cited in note 46). In practice, most Japanese companies that disclose segment information disclose on sales revenues for certain industry groups. Id. 
hierarchy. Such a competitive hierarchy has in the past served as a norm upon which countries could productively base their individual regulatory preferences.

At first blush, foreign disclosure weaknesses may appear to demand regulatory uniformity because of the perception that any country retreating from the norm invites the embrace of managerial opportunism. Yet uniformity need not be the ultimate objective. Strategic reform of individual aspects of securities laws may be a better approach. For example, the disclosure issues posed by the Akai illustration and by line of business reporting contrast with the problems arising from the Japanese treatment of hidden reserves and weak consolidated reporting standards. The former bear on the completeness with which an externally caused event occurs, where the latter openly invite manipulation. Each of these disclosure items raises traditional concerns for the amount of disclosure mandated and the lack of depth and detail in the disclosure. But policymakers should view disclosure items that raise concerns about completeness very differently than those disclosure questions that invite manipulation.

The issue of mandatory disclosure of line of business information points out the classic conflict between those who prepare financial statements and those who use them. To the latter, more disclosure is always better, but to the former, this is not always true. Some fear that absent mandatory disclosure rules, there will be an overexpenditure of societal resources by financial statement users who will needlessly duplicate each other's efforts. ${ }^{60}$ The call for mandatory disclosure on this basis is further enforced by the belief that the security's issuer is likely to have the lowest costs to produce the information and that the issuer's information will be more accurate. A final argument for mandatory disclosure is that absent such rules, there will be delays in disclosure by managers seeking personal gain by capitalizing on their advance knowledge of their company's progress and performance.

At the same time, the reporting company's concerns must also be recognized. Adding depth and detail to financial disclosures entails nontrivial tangible costs, especially when the precise proscription of that depth and

60. Professor Hirshleifer shows how those seeking information predicting future price changes in traded securities will overinvest in the search for information in a pure exchange economy. Jack Hirshleifer, The Private and Social Value of Information and the Reward to Incentive Activity, 61 Am Econ Rev 561 (1971). More recently Professor Stout has extended Hirshleifer's theory to question SEC regulatory initiatives premised in part on improving the efficiency of securities markets. Lynn A. Stout, The Unimportance of Being Efficient: An Economic Analysis of Stock Market Pricing and Securities Regulation, 87 Mich L Rev 613 (1988). In fact, she counsels that "[g]overnment policies that enhance efficiency do so only at the margin." Id at 638. Professor Stout appears to give too much weight to earlier studies by well-recognized critics of mandatory disclosure, see for example, George J. Benston, Required Disclosure and the Stock Market: An Evaluation of the Securities Exchange Act of 1934, 63 Am Econ Rev 132 (1973), and not to consider more fully the weaknesses of those studies. See Joel Seligman, The Historical Need for a Mandatory Corporate Disclosure System, 9 J Corp L 1 (1983) (providing a close analysis of the weakness of studies by Benston and others to conclude their data justify a mandatory disclosure system). 
detail is embodied in technical government directives. ${ }^{61}$ Furthermore, it can easily be foreseen that disclosure of some information may pose serious regulatory and competitive problems for companies doing business internationally. For example, it may well be that line of business information will raise new questions regarding "dumping" violations or whether allocation of tax liabilities among various host nations is consistent with results reported on financial statements. Moreover, disclosure issues cannot always be dictated solely by the needs of financial statement users because, as seen above, as long as the information is a free good to the users of financial information, it will always be over consumed.

The issue posed by the "window dressing" or manipulation possibilities inherent with hidden reserves and weak consolidated reporting requirements touch on a more fundamental concern - the outright discretion of managers to create assets and earnings by their own fiat. In contrast, the Akai Electric illustration and line of business reporting bear on how real transactions, carried out at arm's length, should be reported so that underlying economic events will not be obfuscated. The legerdemain that is permissible with reserve accounting and weak principles of consolidated reporting for subsidiaries has a slightly different effect, obscuring to the user of financial information whether there in fact was a real economic event that explains reported assets, sales, and income. Furthermore, there is little concern for revealing corporate strategic plans or otherwise compromising the corporate interest in those financial reporting areas where lax standards permit window dressing to occur. On the other hand, line of business reporting can frequently pose a dilemma of advancing investor interests at the expense of the reporting corporation.

Thus it would appear that in the realm of disclosure standards, all countries should purge from their financial reporting standards those aspects that permit financial statements to create the false appearance of economic activity. For example, reserve and consolidated accounting should be structured so as to remove the flexibility managers otherwise have to engage in "window dressing." Such a reform effort would not require prohibiting reserves or mandated uniformity in consolidated financial statement standards and practices. Individual differences in these areas pose no serious problems to international markets, provided managers' discretionary reporting choices are sufficiently disclosed. That is, the appropriate international response to reserve accounting and other practices that permit managerial discretion to interdict the accounting reports is not to prohibit such activities but to require transparency. ${ }^{62}$ This can occur, as it does in the

61. For example, a decade ago it was roughly estimated that the costs of the U.S. disclosure system for publicly traded firms was no less than \$1 billion. Susan M. Philips \& J. Richard Zecher, The SEC and the Public Interest 51 (MIT Press, 1981).

62. The above suggestion does not mean that U.S. reporting standards never provide their own opportunities for window dressing. Consider the present collision course between, on the one hand, the SEC's renewed emphasis on companies reporting the fair market value (as contrasted with historical costs) of their investment portfolios and, on the other hand, the Financial Accounting 
United States, by requiring collateral disclosure of the effects of management's accounting choices. The collateral disclosure should be sufficient to permit users of financial statements to extrapolate from the disclosed information what financial results would have come about had management not so exercised its discretion. Such a regulatory response not only assures comparability across all issuers-domestic and foreign-but also rids disclosure choices of the sharpest form of managerial opportunism. In other areas, such as the degree of disclosure that accompanies events such as the announcement by Akai or line of business reporting, individual differences among countries should not be seen as dysfunctional. ${ }^{63}$ On these types of issues, as seen earlier, countries with lax disclosure requirements will find their markets characterized by lower disclosure costs but higher capital costs. In this respect, regulatory competition establishes a useful hierarchy of markets so that issuers may choose the disclosure regime that best fits their needs, and individual countries may pursue their own distinct disclosure philosophies.

\section{IV \\ Accommodating Foreign Issuers: The Limits of the De Minimis Rule}

It is a well-established principle of both choice of law and international public law that deference to the law of a foreign state is justified when that state has the larger contact with a transaction. ${ }^{64}$ Deference is especially called for when applying the foreign state's law would not offend local policy. Recently, the Commission has been sensitive to this approach and restrained its regulatory reach accordingly. Thus, in its releases dealing with crossborder tender offers, ${ }^{65}$ the Commission offered several accommodations in the application of the Williams Act provisions and shortened registration under the Securities Act for multinational tender offers and exchange offers by non-U.S. bidders. In broad overview, the proposed rules will permit a

\footnotetext{
Standards Board ("FASB") Statement No. 12, which currently permits recognizing gains on marketable securities only when they are sold. The present position of the FASB allows companies to engage in "cherry picking," that is, when companies discretely sell those portfolio stocks with gains, they can put a more positive face on their financial performance in what otherwise would be a poor fiscal period. Recently the FASB, under pressure from various financial institutions, refused to succumb to the view being advocated by the SEC, setting the stage for the possibility that the SEC may issue its own reporting standard on the subject. See Lee Berton, FASB Balks on Current-Market Rules for Banks as Member Switches His Vote. Wall Si J A3 col 2-3 (Jan 16, 1992).

63. For example, a disclosure hierarchy exists among U.S. issuers disclosing line of business information in terms of the degree of detail in which information is analyzed in the management discussion and analysis section of the SEC filing. See John W. Bagby, Marilyn R. Kintzele \& Philip L. Kintzele, Management Discussion of Business Performance: An Analytical and Empirical Evaluation, 26 Am Bus L J 57, 84-96 (1988).

64. See, for example, Restatement (Third) of Foreign Relations Law of the United States 401 03, 416 (1986). See generally Robert W. Hillman, Cross-Border Investment, Conflict of Laws, and the Privatization of Securities Law, 55 L \& Contemp Probs 331 (Autumn 1992).

65. Securities Act Rel No 6897, and Exchange Act Rel No 29275 [1991 Transfer Binder] Fed Secur L Rptr (CCH) \ 84,803 (1991).
} 
non-U.S. bidder to comply primarily with foreign disclosure, procedural, and accounting requirements, and in exchange will allow the bidder to fulfill its U.S. disclosure obligations through use of its home country's listing requirements. These accommodations apply only where the target shares held by U.S. investors constitute a small portion of the outstanding shares of the target company. ${ }^{66}$

The initial appeal of these proposals is that absent such accommodations, U.S. holders stand a very good chance of being excluded from the tender or exchange offer. This concern is embodied in the condition that the proposals on the tender or exchange offer not have a substantial impact on U.S. investors when viewed in the context of all the outstanding shares of the target corporation. The accommodations advance the interests of both foreign bidders and U.S. holders, placing the latter on an equal footing with their foreign counterparts. Otherwise, if U.S. holders could not participate in the tender offer, the bidder could acquire its shares later, through a disadvantageous freezeout merger, which could occur without compliance with U.S. disclosure rules. Also, from a corporate governance perspective, there should be less U.S. concern when the target corporation is owned mainly by holders who do not reside in the United States. The profile of such a corporation suggests its business operations are also significantly outside the United States.

In making these proposals, the Commission suggests that concerns for U.S. holders outweigh any complaint about horizontal unfairness advanced by a U.S. competing bidder. The U.S. bidder may be frustrated that its foreign rival enjoys greater freedoms with respect to proration, withdrawal rights, and disclosure such that the U.S. bidder operates at a serious disadvantage. ${ }^{67}$ One would expect that the second shoe to drop will be a greater willingness on the Commission's part to assure a truly level playing field by freely granting to such a competing U.S. bidder exemptions from those provisions of the Williams Act that the foreign bidder is not burdened by as a consequence of the exemptions now proposed by the SEC.

So viewed, it would appear that cross-border tender and exchange offer proposals can be normative in guiding relaxation of U.S. securities laws in the

66. Relief from the Williams Act provisions applies so long as the U.S. security holders own $10 \%$ or less of the class of securities sought in the tender offer. With reference to relief from $\$ 5$ registration when an exchange offer is made by a non-U.S. bidder, proposed Rule 802 applies if the value of the securities being offered does not exceed $\$ 5$ million, and registration on proposed Form F-12 will be available if the securities held by U.S. holders prior to the exchange offer are no more than $10 \%$ of the securities sought in the exchange.

67. For example, one theme of the federal takeover rules is the facilitation of an auction for the firm by removing some of the pressure on target shareholders to tender their shares. Thus Rule 14d8 , which pro rates the bidder's acceptance of its oversubscribed offer at the end of the offer rather than at some earlier time, and Rule 14d-7 extend the right to withdraw tendered shares up to the close of the offer. In the absence of such provisions, the target shareholders could be unduly pressured to tender quickly or face proration, or if a competing offer appeared, would not be able to withdraw previously tendered shares. One can thus see how a U.S. bidder competing with a foreign bidder could be disadvantaged if the foreign bidder did not have to comply with takeover rules that were binding on the U.S. bidder. 
face of conflicting regulation abroad. Deference to the home country regulation would appear justified whenever the particular regulatory issue has a de minimis connection to U.S. markets. Such a principle, however, provides only a momentary respite from the disproportionate rigor of U.S. securities laws.

To illustrate, consider how the de minimis rule fails to overcome the anticompetitive effects of U.S. distribution rules. The most pervasive of the distribution rules is Rule $10 \mathrm{~b}-6,{ }^{68}$ which prohibits key participants in a distribution of securities from artificially enhancing the offering's appearance to investors through simultaneous market purchases that nudge the price upwards. Those who purchase a distributed security, however, frequently resell the security in its aftermarket. Excessive selling in the after market makes it more difficult for the underwriters to dispose of their unsold allotments; this is particularly true if such selling pressure causes the price of the distributed security to decline below its offering price. Designed to counteract this effect, Rule 10b-769 authorizes stabilizing purchases during a distribution. The dual effects of complying with Rule 10b-7 are that purchases are not deemed to be manipulative or deceptive, as that term is used in Section 10(b) of the Exchange Act, and, furthermore, that the purchases and bids do not violate Rule 10b-6's bar to purchases during a distribution..$^{70}$ Rule 10b-7's requirements are many, and all are technical, but, in general, the rule limits the stabilizing bids and purchases to one price, which generally is the security's last independently established sales price. ${ }^{71}$

To illustrate the disjunction that such complex distribution rules pose to globalized offerings, consider the regulatory framework that applies to offerings that occur over the London Stock Exchange. Section 47(2) of the Financial Services Act embodies Britain's equivalent to the United States' Rule 10b-5 in its proscription of "engag[ing] in any course of conduct which creates the false or misleading impression as to the market in or the price" of a security. The Financial Services Act has no equivalent to Rule 10b-6's prophylactic proscription, but pursuant to its powers under the Act, ${ }^{72}$ the Securities and Investments Board, as part of its business conduct rules, has issued somewhat technical rules permitting stabilization during a security's distribution. ${ }^{73}$ Within this framework, the conflict in regulatory patterns is not among the proscriptions of manipulation or with the differing approaches toward stabilizing purchases (although the latter does indeed pose a conflict to the extent they do not replicate one another).

\footnotetext{
68. 17 CFR $\$ 240.10 \mathrm{~b}-6$ (1992).
}

69. 17 CFR $\$ 240.10 \mathrm{~b}-7$.

70. Similarly, Rule $10 \mathrm{~b}-8$ is designed to facilitate rights offerings by allowing its distribution participants to bid for and purchase the rights and their underlying security, within certain limits.

71. Rule 10b-7(j)(1), 17 CFR § 240.10b-7(j)(1).

72. Financial Services Act $\$ 48(7)$ (1986) (Eng).

73. Securities and Investments Board, 1987 Rules, Rule 10.05. See generally Norman S. Poser, International Securities Regulations 136 (1991). 
As the Commission has recently recognized, Rule 10b-6 creates an ongoing conflict with practices and methods of distributing securities abroad. ${ }^{74}$ Some of the conflict may be relieved by Commission proposals to exempt from the distribution rules (but not the overall antifraud provisions) certain international rights offerings. ${ }^{75}$ Also, through its no-action letters, the Commission has selectively granted exemptions from its distribution rules. ${ }^{76}$ In each case, the exemption was premised in part on the stipulation that no such purchases or bids be effected in the United States and that they occur on a "designated offshore securities market,"77 the latter being one that the SEC has approved in part because of the existence of foreign government oversight.

To be sure, the concessions the Commission has made in exempting foreign issuers from the distribution rules have been cautious and limited in scope. They are based on the same de minimis reasoning as the proposed cross-border tender and exchange offer exemptions. But note how different an issue is posed by relaxing the distribution rules when securities are simultaneously offered in the United States and abroad, and when there is reason to expect arbitrage across markets to have an impact on the price in U.S. markets. The anticompetitive effect of this approach is that, from the U.S. perspective, it creates the wrong incentive. Exempting conduct that

74. Securities Act Rel No 6896, Fed Secur L Rptr (CCH) ๆ $81,715,81,727$ (1991).

75. The proposed exemption will apply to rights offerings qualifying to use proposed Rule 801, which is limited to offerings not exceeding $\$ 5$ million or those that can utilize proposed Form F-11, which incorporates in its entirety the disclosure requirements of the issuer's home jurisdiction.

76. See, for example, The International Stock Exchange of the United Kingdom and the Republic of Ireland Ltd. (Sept 29, 1987), Fed Secur L Rptr (CCH) ๆ 78,713 (1987).

77. The relevant regulation provides as follows:

(a) Designated Offshore Securities Market. Designated offshore securities market means:

(1) The Eurobond market, as regulated by the Association of International Bond Dealers; the Amsterdam Stock Exchange; the Australian Stock Exchange Limited; the Bourse de Bruxelles; the Frankfurt Stock Exchange; The Stock Exchange of Hong Kong Limited; The International Stock Exchange of the United Kingdom and the Republic of Ireland, Ltd.; the Johannesburg Stock Exchange; the Bourse de Luxembourg; the Borsa Valori di Milan; the Montreal Stock Exchange; the Bourse de Paris; the Stockholm Stock Exchange; the Tokyo Stock Exchange; the Toronto Stock Exchange; the Vancouver Stock Exchange; and the Zurich Stock Exchange; and

(2) Any foreign securities exchange or non-exchange market designated by the Commission. Attributes to be considered in determining whether to designate such a foreign securities market, among others, include:

(i) Organization under foreign law;

(ii) Association with a generally recognized community of brokers, dealers, banks, or other professional intermediaries with an established operating history;

(iii) Oversight by a governmental or self-regulatory body;

(iv) Oversight standards set by an existing body of law.

(v) Reporting of securities transactions on a regular basis to a governmental or selfregulatory body;

(vi) A system for exchange of price quotations through common communications media; and

(vii) An organized clearance and settlement system.

17 CFR § 230.902 (1992). 
occurs beyond U.S. shores most surely will direct more and more transactions overall to foreign markets. ${ }^{78}$

This market exodus will not occur with the exemption proposed for crossborder tender and exchange offers. The effect of this exemptive action is not to drive the tender offer to another country's markets, but rather to assure equal participation for U.S. residents in a tender offer that otherwise meets the minimal disclosure and procedural requirements of a foreign country. Just as Willie Sutton robbed banks because "that's where the money is," 79 the United States can continue to impose its own tender offer rules for those companies of which a majority of the stock is held by U.S. residents, without fear of otherwise leaving them to the vices of a "back-end freezeout." But when U.S.-based ownership is so slight that control can be acquired by the bidder without extending a bid to the U.S. holders, concerns of equal participation overwhelm the application of U.S. tender offer rules. In contrast, the distribution rules are not within Willie Sutton's sage advice, for money and markets are everywhere, certainly not exclusively in the United States. Thus, discrete exemptions from the distribution rules based on the transaction's minimal contact with U.S. markets only assures that U.S. markets will be increasingly disfavored by those laying the venue for globalized offerings.

The impact that internationalization has had on the SEC's exemptive powers and construction of the distribution rules is a dramatic illustration of overregulation that has far-reaching effects. That Rule $10 \mathrm{~b}-6$ is one of the most frequent subjects of no-action letter requests ${ }^{80}$ is strong evidence that the breadth of the rule's prohibitions touches legitimate and commercially necessary transactions in its attempt to shield a distributed security's price

78. Its exemptive activities, however, underscore both the well-recognized breadth of Rule $10 \mathrm{~b}-$ 6 in particular and how seriously out of step Rule 10b-6 is with the distribution rules that apply in other countries. It would appear beyond doubt that the overall force of recent Supreme Court cases is that a violation of Rule $10 \mathrm{~b}-6$ cannot occur without a substantial showing of both deception and scienter, neither of which, however, are within its lengthy elaborate proscriptions. Because the rule threatens and thereby regulates those whose behavior lacks a proscribed intent, its impact on the competitiveness of U.S. securities markets is very different from that of a pure antifraud provision. As seen above, the latter does not discourage the conduct of legitimate business transactions, while its aggressive enforcement enhances the overall luster of U.S. exchanges. In contrast, the distribution rules, like the rain, fall on the good and the bad alike, and the available evidence further points to the fact that Rule 10b-6 visits social costs greatly in excess of its gain. This appears evident from the tremendous volume of no-action letters granted for Rule $10 \mathrm{~b}-6$ balanced against the extremely slender number of successful prosecutions under that rule.

79. United States v Darby, 857 F2d 623, 630-31 (9th Cir 1988) (quoting State v Zayas, 490 A2d 68, 73 (Conn 1985)). But did he really say it? Willie Sutton denies he did, "The irony of [the quote is] .. the fact that I never said it. The credit belongs to some enterprising reporter who apparently felt a need to fill out his copy. I can't even remember when I first read it. It just seemed to appear one day, and then it was everywhere." Willie Sutton, Where the Money Was 120 (Viking Press, 1952). See also Paul F. Boller, Jr. \& John George, They Never Said $I t-A$ Book of Fake Quotes, Misquotes, and Misleading Attributions 121 (Oxford U Press, 1989). The author's firm belief is that the statement makes so much sense, anyone should be proud to claim making it, and he does.

80. Two other regulatory provisions that rival Rule 10b-6 in this area are Rule 144, 17 CFR $\$ 230.144$ (1992), dealing with resales of restricted and control securities and the newly adopted rules under section 16 of the Exchange Act, which expands the reporting requirements for purchases and sales of securities by the officers and directors of large, public corporations. 
from contrived demand. A regulatory approach that depends so heavily on the informal exemptive process of no-action letters places U.S. issuers and markets at a serious disadvantage to those who place the venue of the transaction elsewhere. So viewed, the concessions the SEC has extended to globalized offers are much like sweeping the litter under the rug. The problem is removed from sight, but not beyond our feet. ${ }^{81}$

\section{Evidence of Competitive Disequilibrium in the United States}

The problem with the model of intermarket competition suggested by capital market theory is that its utility lies in its abstract arraying of capital markets in a hierarchy according to the strictness of their regulatory demands. The image lacks concreteness, however. It has no predictive capability as to whether a precise regulation or group of regulatory initiatives will yield benefits commensurate with their costs. One wishing to move from the model's abstract prescription to a specific policy position may well find the model a somewhat empty standard. Because the competition among markets is adjudged on the synergistic whole of a nation's regulations versus those of competing markets, the model will be of little value in gauging whether a specific regulatory issue will place the country at a competitive disadvantage overall. The model is useful, however, in characterizing the status quo so that policy judgments can be made with a healthy awareness of where the individual country is on the regulatory continuum. The data below make such a review and offer a not-too-reassuring assessment of the competitiveness of U.S. securities laws.

The evidence suggests that the disclosure system embodied in U.S. federal securities laws is not in the competitive equilibrium described in Part II. Recall that in such an equilibrium state, the higher disclosure costs in the United States are expected to be accompanied by lower capital costs, and the lower disclosure costs of foreign markets are expected to be accompanied by higher capital costs. Unless there is some reason to expect a bias favoring lower disclosure costs over lower capital costs, one would not expect to find over time any systematic defection by issuers or investors from one market to

81. There is ample reason to believe that the overregulation the SEC has achieved through its distribution rules, and especially Rule 10b-6, if challenged, would be held to be an invalid exercise of rulemaking power. The enabling provision for the distribution rules is $\S 10(\mathrm{~b})$ of the Exchange Act, which the Supreme Court has held to require scienter by the defendants. SEC v Aaron, 446 US 680 (1980). Within $\$ 10(b)$ the operative language upon which the distribution rules rely is "manipulative," which language the courts have interpreted to require proof that a series of trades were undertaken with the specific intent to affect the security's price. See United States $v$ Mulheren, 938 F2d 364 (2d Cir 1991) (dismissed because no specific intent found); United States $v$ Regan, 937 F2d 823 (2d Cir 1991) (upholding finding that evidence supported finding specific intent to manipulate).

In spite of these authorities, Rules $10 \mathrm{~b}-6$ and $10 \mathrm{~b}-7$ do not incorporate a specific intent requirement. Against this background, the reasoning of a leading Rule 10b-6 case, Jaffee $\mathcal{E}^{2} \mathrm{Co}$. $v$ Securities and Exchange Commission, 446 F2d 387, 391 (2d Cir 1971), that the Commission "need not have shown that Jaffee actually intended to defraud the marketplace through his purchases," appears no longer valid. See generally Fred N. Gerard \& Michael Hirschfeld, The Scienter Requirement under Rule 1Ob-6, 46 The Bus Lawyer 777 (1991). 
the other. Yet the following data strongly support the view that, overall, the marginal cost of mandated disclosure in the United States overwhelms the resulting benefit.

Foreign issuers who list their shares on U.S. exchanges or who offer their securities in the United States subject themselves to U.S. disclosure laws. The data show a serious imbalance between the eagerness of foreign firms to expose themselves to U.S. securities laws and the willingness of U.S. firms to list and raise capital abroad. Consider that in 1986, 199 U.S. firms were listed on the London Stock Exchange, whereas only forty-nine foreign companies' shares were listed on the New York Stock Exchange.82 Far more revealing here is a comparison between the United States and a specific foreign country's experiences. In 1989, sixty-seven U.S. corporations listed their shares on the Tokyo Stock Exchange, compared to only eight Japanese corporations that listed their shares on the New York Stock Exchange and none listing on the American Stock Exchange or NASDAQ. Additionally, only sixteen Japanese American Depositary Receipts ("ADRs") are traded on NASDAQ ${ }^{83}$ In contrast, ninety-three Japanese firms are admitted for listing on the London Stock Exchange. ${ }^{84}$ The far larger number of Japanese firms listing their shares on the London Stock Exchange than on any U.S. exchange or NASDAQ is consistent with the view that Japanese companies (and certainly other foreign issuers) do not find that the benefits of listing their shares in the United States provide sufficient reward for the additional disclosure duties and associated costs. Such data elicited a bit of understatement from the SEC's staff: “U.S. stock markets have not kept pace with other stock markets around the world in attracting foreign listings." 85

Further evidence that the United States is inhospitable to foreign issuers is that in 1977 registered public offerings by foreign issuers represented thirteen percent of all registrations (in dollar amount), whereas by 1986 this had fallen to three percent. ${ }^{86}$ Even this figure does not tell the whole story. Approximately sixty-four percent of the foreign registrations in the United States are by foreign governments, so that it is safe to say that the United States plays a minuscule role in the capital raising activities of private foreign companies, and the foreign companies that so tap United States investors are most frequently Canadian. ${ }^{87}$ In contrast, U.S. firms in 1986 issued about

82. Report on Internationalization of Securities Markets before the Senate Committee on Banking, Housing, and Urban Affairs and House Committee on Energy and Commerce, 100th Cong, 1st Sess II-64 (July 27, 1987) (report by the staff of the SEC) ("1987 SEC Staff Report"). It should be noted that there were 52 foreign firms listed for trading on the Tokyo exchange. Id. The London Stock Exchange still has more listings than all United States exchanges, which had 123 foreign equities in 1986, up only slightly from 116 equities ten years earlier. Id at II-82.

83. Terry M. Chuppe, Hugh R. Haworth \& Marvin G. Watkins, The Securities Markets in the 1980's: A Global Perspective (1989). The number of Japanese firms listed on the New York Stock Exchange increased to nine by January 1992. (Letter on File with office of Law and Contemporary Problems.)

84. Letter to Professor James D. Cox from the London Stock Exchange (June 6, 1991) (on file with the office of Law and Contemporary Problems).

85. 1987 SEC Staff Report at II-81 (cited in note 82 ).

86. Id at II-82.

87. Id at II-82 to -83 . 
twenty-five percent of their bonds through offerings in foreign countries, whereas in 1980 they raised only about twelve percent internationally. ${ }^{88}$ Similar growth in raising capital abroad can be found for funds raised by issuing equity securities abroad. ${ }^{89}$

Both the reluctance of foreign issuers to list their shares for trading in the United States and the larger number of U.S. issuers who raise capital abroad point to a single financial truth: the overall rewards of investing and raising capital abroad are greater than the discounting that occurs due to less demanding foreign disclosure standards.

In contrast to the data concerning foreign and U.S. issuers, the data show that foreign investors trade in U.S. markets far more often than U.S. investors trade in foreign markets. Government statistics reveal that in 1989 foreign purchases and sales in U.S. securities markets was $\$ 416$ billion, whereas purchases by U.S. residents in foreign markets was $\$ 230$ billion. ${ }^{90}$ Equally interesting is recent data gathered by Solomon Brothers, International, Ltd., on international stock purchases. Its report shows that U.S. investors will purchase more than twice as much in dollar amounts of foreign stocks as foreign traders will purchase in U.S. markets. ${ }^{91}$ To add perspective, foreign investment in U.S. stocks in 1991 will be $\$ 14.2$ billion, in Japanese stocks will be $\$ 31.6$ billion, and in British stocks will be $\$ 7.4$ billion. ${ }^{92}$ The data suggest a growing interest on the part of U.S. investors to diversify their portfolios internationally and a continuing interest of foreign investors to do the same. The disproportionate interest in foreign residents' purchases in the United States versus U.S. residents' purchases abroad is consistent with the thesis that efforts to assure the overall fairness of U.S. securities markets make those markets more attractive havens for investment activity.

It is upon this philosophy that the United States' aggressive pursuit of insider trading, misleading financial reports and announcements, market manipulation, and prophylactic distribution rules find their primacy. The beneficiaries are not solely investors, but are also the many local financial intermediaries who feast upon those flocking to partake in the world's cleanest markets. Nevertheless, the above data strongly suggest that U.S. markets are not attractive to foreign issuers, who much prefer to raise their capital elsewhere. The concern of foreign issuers is not solely the greater disclosure demands that apply to them when they offer their securities for sale or list their shares on U.S. exchanges. They also have a quite legitimate fear of the prevalence of securities fraud class actions. The next two sections

88. Id at II-87.

89. Id at $11-55$ to -57

90. These figures represent all securities trading. Office of the Secretary, U.S. Department of Treasury, Treasury Bulletin table CM-V-5 (Spring 1990).

91. More precisely, in 1991 U.S. citizens were expected to invest $\$ 26.3$ billion in foreign stocks (compared to $\$ 11.9$ billion in 1990), and foreign investors were expected to purchase $\$ 14.2$ billion of U.S. stocks (compared to an overall net withdrawal from U.S. markets of $\$ 15.1$ billion in 1990). Michael R. Sesit, U.S., Europe Take the Lead in Global Stock Investments, Wall St J Cl col 2-3 (Oct 17, 1991).

92. Id. 
suggest ways in which U.S. securities laws can address these concerns without weakening their disclosure rules.

\section{Making U.S. Disclosure Requirements Competitive}

Because the experiences discussed above minimally challenge the existing disclosure orthodoxy, it is appropriate to reexamine the overall content of U.S. disclosure rules. At one time, this reexamination would have been viewed as throwing in the towel much too soon. The attitude through much of the 1980s was that the United States should use its exulted disclosure standards as a "bully pulpit" by which to raise the disclosure standards of other countries. This, of course, has been tried and has met with some success. It is now clear, however, that at least European disclosure practices ${ }^{93}$ have evolved about as far as can be expected. The hard-line negotiations that have produced some movement in the European Community, and Britain especially, must now give way to reconciliation. It is clearly time to turn our attention to our own disclosure requirements. A few principles will guide this evaluation.

\section{A. Asymmetric Disclosure Rules}

In overview, I foresee the need for a major shift in emphasis in Regulations S-X and S-K. Minimally, the utility of their numerous requirements must. be reassessed in light of the listing requirements of competing jurisdictions. But more is required than this. Quite independent of the type of comparative review suggested above, the demands of Regulation S-X and S-K should be reduced substantially. In making this second level of review, the Commission should not be neutral in its prescriptions between the disclosure of "good" news and "bad" news. The approach suggested here, while at first appearing to accept the thesis of the Chicago School, includes an important modification. Those who prefer Adam Smith's invisible hand to the heavy hand of the Commission have long advised that managers have natural incentives to disclose information.94 The traditional pro-regulatory view is that reporting requirements are necessary because managers lack sufficient incentives to disclose trustworthy corporate information. There is also the fear that absent mandatory disclosure rules, managers will disclose material information only after they have exploited its value for private gain by insider trading. Those who counsel a laissez-faire disclosure regime, meanwhile, argue that managers will engage in necessary

93. See, for example, Harmony and Wariness Coexist at ISOCO's Conference in Venice, 2 Intl Sec Reg Rep (BNA) No 20 at 1 (Sept 27, 1989) (reporting that at the annual meeting of the International Organization of Securities Commissions, members expressed resistance to increasing their regulation of securities transactions).

94. See, for example, George J. Benston, Required Disclosure and the Stock Market: An Evaluation of the Securities Exchange Act of 1934,63 Am Econ Rev 132 (1973); George J. Stigler, Public Regulation of the Securities Markets, $37 \mathrm{~J}$ Bus 117 (1964). 
voluntary disclosure because such disclosure not only increases the value of their firm, but also maximizes the managers' utility: ${ }^{95}$

To see how this works, take a simple example of a firm that wants to issue new securities. The firm has a project ... that it expects to be profitable. If the firm simply asked for money without disclosing the project and managers involved, however, it would get nothing. Investors would assume the worst, because they would reason that if the firm had anything good to say for itself it would do so. Silence means bad news. A firm with a good project, seeking to distinguish itself from a firm with a mediocre project (or no project at all), would disclose the optimal amount of information. That is, it would disclose more and more so long as the cost of disclosure (both direct costs of dissemination and indirect costs of giving information to rivals) was worthwhile to investors as a whole....

The process works for bad news as well as for good news. Once the firm starts disclosing it cannot stop short of making any critical revelation, because investors always assume the worst. It must disclose the bad with the good, lest investors assume that the bad is even worse than it is. And the firm cannot stand on its say-so alone. Mere disclosure would be enough if the rule against fraud were perfectly enforced, but it is not. Thus the firm uses . . verification and certification devices. ${ }^{96}$

The most glaring weakness in the view that mandatory disclosure rules are unnecessary is the assertion that managers approach disclosure of bad news with the same fervor as good news. All studies of voluntary disclosure practices, and even studies of mandatory disclosures, reveal a distinct managerial bias against disclosing "bad" news. Whether the subject studied is the voluntary release of a financial forecast or the release of the company's annual report (the disclosure of which is mandated by the securities laws), the results are consistent; management systematically avoids release of "bad" news forecasts and delays the release of mandated information when that information is "bad" news. ${ }^{97}$ Moreover, insiders appear not only to trade in their company's stock before the release of a financial forecast, but the strength of the correlation between the frequency of insider purchases and their forecasts is directly related to the forecast's ultimate impact on the stock's price. ${ }^{98}$ Hence, insiders appear to be excellent judges of whether an upcoming forecast is likely to affect materially their stock's price.

Even though the evidence does not support the laissez-faire world counselled by the Chicago School, it does support a reorientation of present disclosure rules. Not surprisingly, there is far greater reluctance to disclose "bad" news than "good" news, and there is evidence that insiders capitalize on their advance knowledge of the disclosure by trading in their corporation's

95. See generally Stephen A. Ross, Disclosure Regulation in Financial Markets: Implications of Modern Finance Theory and Signaling Theory, in Franklin R. Edwards, ed, Issues in Financial Regulation 177 (McGraw-Hill, 1979); see also Michael C. Jensen \& William H. Meckling, Theory of the Firm: Managerial Behavior, Agency Cost and Ownership Structure, 3 J Fin Econ 305 (1976).

96. Frank H. Easterbrook \& David R. Fischel, Mandatory Disclosure and the Protection of Investors, 70 Va L Rev 669, 682-83 (1984).

97. For a full review of these studies, see James D. Cox, Insider Trading Regulation and the Production of Information: Theory and Evidence, 64 Wash U L Q 475 (1986).

98. See Stephen H. Penman, Insider Trading and the Dissemination of Firm's Forecast Information, $55 \mathrm{~J}$ Bus 479 (1982). For a discussion of how the manager's insider trading can be harnessed to the goal of signaling the authenticity of financial announcements, see Cox, 64 Wash U L Q at 475, 502-05 (cited in note 97 ). 
stock. Curbing the frequency of insider trading cannot be a justification for the status quo disclosure requirements. Reports filed under section 16 of the Exchange Act show that corporate insiders systematically garner abnormal returns by trading in their corporation's shares; ${ }^{99}$ given the natural incentives to release "good" news and the discretion managers enjoy to delay the release of mandated "good" news where there are competing business justifications for delaying disclosure, it would appear public policy would not be seriously affronted if the orientation of our mandatory disclosure rules tilted toward the regulation of "bad" news rather than "good" news. The evidence supports the view that relaxing disclosure guidelines as they pertain to information having a materially favorable impact on the firm's financial position and performance would not operate to the disadvantage of investors. On the other hand, the proper role of disclosure guides should be to mandate disclosure of the type of information that management is less likely to disclose. ${ }^{100}$ If this approach were taken, it would also accommodate the competitive concerns raised in the next section.

\section{B. Weighing the Competitive Disadvantages of Disclosure}

For twenty-five years after World War II, both U.S. industry and its regulators basked in the comfortable climate the devastation of Europe and Japan left at its commercial door. Certainly disclosure demands could be more easily imposed when the dent of competition was felt only by those subject to the same rules. Although the world has become a much more competitive environment in the past two decades, the regulatory mentality has not kept pace with the changes in commercial markets and regulatory pressures from abroad. Certainly disclosure requirements cannot be formulated with a blind eye to the competitive business climate within which U.S. registrants operate. This is a factor that needs consideration and again calls for the comparative approach recommended above. To move from rhetoric to a more concrete analytic approach, the next section examines the disclosure issues posed by two items that are not common in foreign countries-quarterly reports and line of business reporting.

There can be no serious question about the utility of quarterly reports and lines of business disclosures to investors. Their materiality is documented by a string of event studies that reflect the utility of this information to investors. Despite the recognized value of quarterly report and line of business information, the United States stands alone in mandating disclosure of each for its domestic issuers. Interestingly, the United States does permit some

99. See, for example, James H. Lorie \& Victor Neiderhoffer, Predictive and Statistical Properties of Insider Trading, $11 \mathrm{~J} \mathrm{~L} \&$ Econ 35 (1968).

100. See, for example, In the Matter of Caterpillar Inc, SEC Admin Proceeding File No 3-7692 (Mar 31, 1992), where SEC charged the company with failing to inform investors that nearly $25 \%$ of its 1989 earnings came from Brazil and failed to warn that such a strong performance was unlikely to recur in 1990. 
modest escape from its requirements for foreign issuers. ${ }^{101}$ Indeed, line of business reporting has been the item most frequently singled out by foreign issuers who complain about the disclosure demands of Regulation S-K.

Quarterly reports and line of business information are similar in that they both contain information already in possession of management. As part of management's stewardship of the firm, managers will have such reports prepared for them on a regular basis. To be sure, if quarterly reports were not mandated, it may be that managers would prefer a different reporting method, although it would nevertheless be bound by the necessity of an annual report to the stockholders. If a firm has two or more significant divisions, the managers have an obligation to the firm and its owners to disaggregate the total firm data, at least for those divisions that constitute a large portion of the total firm's assets or contribute a significant portion of its sales and earnings. So viewed, the impact of mandating disclosure of quarterly and line of business information is incremental; the cost is incurred in any case when supplying managers with information necessary for their stewardship of the firm. The complaints of foreign issuers that they should be exempt from these disclosure demands, therefore, appear insubstantial, because it is quite likely that this information is already within their record keeping and internal reporting systems so that the cost of making it publicly available is minimal.

But the costs of disclosure are not simply the costs of generating the mandated information. Disclosure costs also include some assessment of the competitive disadvantages of making public what otherwise is proprietary information. In this regard, there is a great difference between the issue of mandating quarterly reports and mandating line of business information. Intuitively, consideration of the anticompetitive effects of disclosure has more weight in the line of business area than with quarterly reports because the former is more likely to reveal ongoing business strategies vis-à-vis competitors. The costs of such revelation may take the form of attracting the competitors' attention to market or product areas where extraordinary returns are being garnered. Such disclosure may also erode the advantage of surprise by identifying undertakings where substantial assets are being committed. These same concerns do not arise with quarterly reports because individual product or market areas are not singled out for disclosure.

In 1984, the SEC proposed that line of business information be reported quarterly. In the face of strong opposition, the proposal was dropped. Among the complaints were those of established securities lawyers who questioned the benefits of such disclosure in view of the related costs. In their view, such information was softer than other mandated information because of the need in interim reports to rely upon arbitrary assumptions on allocating overhead and other shared costs among different divisions within the

101. Form 20-F, the reporting form for Foreign Issuers under the Exchange Act, requires segmental information only for revenues. See Exchange Act Form 20-F General Instructions, 17 CFR § 249.220f (1992). 
company. ${ }^{102}$ Later, then-Commissioner Grundfest questioned whether the quest for additional segmental reporting would produce any benefits in light of the ample evidence that those to gain most from such disclosure would be analysts less resourceful or skillful than other analysts at forecasting performance of individual lines of business. ${ }^{103}$ This argument again highlights the weaknesses of premising disclosure requirements on the information needs of users; even if all analysts would benefit from the additional information, it is impossible to determine the true cost-and-benefit relationship, because, in individual cases, firms may be seriously disadvantaged by making this information available. If given the opportunity, all firms could choose to insure against the potential disadvantage by offering and listing their shares in a foreign market.

The new consideration advanced here is that even though information may be readily available, the Commission needs to exclude categories of information from mandatory disclosure requirements where disclosure of that information may place issuers at a competitive disadvantage. Concern over this disadvantage is not entirely neutralized by merely embracing the earlier suggested approach toward the disclosure of adverse information rather than positive information. The suggestion was directed in part toward reducing overall disclosure costs by reducing the amount of information required to be assembled, evaluated, and disclosed. Line of business information, however, illustrates the type of information that is regularly available to issuers, such that there are no significant new costs visited upon the issuer to generate the information. Nevertheless, as noted above, disclosure of the information can have distinct costs to the issuer. A far wiser approach to such areas is to permit issuers to distinguish themselves by the degree of segmental information they wish to reveal, leaving it to analysts to fill in the gaps with alternative sources of information or by more heavily discounting the shares of those companies whose disclosures are not as richly detailed and revealing. ${ }^{104}$

The potential anticompetitive effects of disclosure transcend line of business reporting and touch a wide array of disclosure items. The more useful approach, therefore, and the one advocated here, would be for the SEC to adopt a safe harbor that permits confidential information to be withheld by registrants when management has a reasonable basis to believe that the best interests of the company-or more particularly, its owners-are served by nondisclosure. Consistent with the earlier recommendation that the focus of

102. See ABA Panel Members Oppose SEC Proposal to Increase Interim Segment Reporting, 16 Sec Reg \& L Rep (BNA) 929 (May 25, 1984).

103. Grundfest Stresses Economic Efficiency as Goal of Commission, Securities Laws, 18 Sec Reg \& L Rep (BNA) 1351, 1354 (Sept 19, 1986).

104. This indeed is, according to Commissioner Grundfest, what appears to be the case with quarterly reporting of segmental information. Id. One can take this step further and suggest that no mandated line of business information is required, thus allowing issuers to array themselves on this issue according to the degree each issuer discloses, with higher discounting for those issuers who disclose the least. 
mandatory disclosure be heavily oriented toward negative information, the safe harbor would be limited to prospective plans, events, and negotiations as well as existing conditions, the premature disclosure of which would either thwart or seriously threaten the expected corporate gains. The safe harbor would in some degree codify the reasoning of State Teachers Retirement Board $v$. Fluor Corp. ${ }^{105}$ which held Fluor had not breached its disclosure obligations by failing to announce it had secured a significant contract with South Africa where the terms of that contract required that the announcement be delayed for about two weeks to permit the South African government to secure financing from a rival bidder. The proposed safe harbor would not allow a corporation to engage in affirmative misstatements, however. For example, the business justification advanced here is not intended to reverse Basic, Inc. $v$. Levinson, ${ }^{106}$ which held that a denial of ongoing merger negotiations, when in fact the firm was actively engaged in such negotiations, could be material misrepresentation. ${ }^{107}$ In a sense, the safe harbor would bring SEC disclosure requirements-at least as to forward-looking, positive information-in line with prevailing listing requirements on the exchanges. ${ }^{108}$ Creating a safe harbor would be more efficient than conducting a wholesale review of all SEC disclosure requirements to identify those likely to pose competitive disadvantages. Because nearly any disclosure requirement in a particular setting poses such a disadvantage, it is difficult to identify those deserving of relaxation. ${ }^{109}$

105. 654 F2d 843 (2d Cir 1983).

106. 485 US 224 (1988).

107. Similarly, the Supreme Court rejected the argument that opinions of a transaction's merits that are inconsistent with the underlying facts of those opining can give rise to a misrepresentation because it constitutes a half-truth. Virginia Bankshares v Sandberg, - US -, 111 S Ct 2749 (1991). The classic illustration of serving the corporate interest at the expense of investors and even stockholders is Heit $v$ Weitzen, 402 F2d 909 (2d Cir 1968), where false, pessimistic financial statements were issued so as to hide from the government overcharges on government contracts. The safe harbor proposed above would not change the Heit court's ruling that an "ulterior motive" does not shield the corporation from its responsibility to avoid materially misleading public announcements.

108. See New York Stock Exchange Listed Company Manual, Rule 202.05 (interpreted to permit disclosure delay for legitimate business purpose. Cf Fluor, 654 F2d 843) and American Stock Exchange Guide (CCH) ๆ 10,122 (1991) (delay permitted if disclosure would prejudice the ability of the company to pursue its corporate objective). In contrast, NASDAQ has no stated business purpose exception. See National Association of Securities Dealers Manual, schedule D, pt II, $1(\mathrm{c})(15)(1986)$.

109. Professor Langevoort has also urged that registrants be allowed to withhold confidential information subject to a balancing test whereby the company's interests outweigh the need for prompt disclosure. Donald C. Langevoort, Information Technology and the Structure of Securities Regulation, 98 Harv L Rev 747, 791 (1985). To assure the business justification for nondisclosure is fairly weighed, he commends the decision to the directors or senior management. Id at 792 . His proposal appears to involve uncertainty over whether the ex ante weighing will be the same as that made by a court ex post and also requires proof of "significant risk of financial harm to the shareholders" by disclosure. Id at 791. These qualifications appear to restrict access to the safe harbor by robbing the provision of its certainty. 


\section{Squeezing the Balloon: The Problem of Relaxing Formal Disclosure REQUIREMENTS}

While not everyone will admit to it, most have at one time or another delighted in squeezing a balloon. Air rushes from beneath one's hands, causing another part of the balloon to swell. If the balloon is squeezed too hard, it pops. Similarly, even if the mandatory disclosure obligations set forth in Regulations S-X and S-K are reduced, the disclosure demands can be expected to reappear (that is, "pop out") under the pressures of the antifraud provisions of the securities laws. It is, of course, the antifraud provisions that add not just discipline to the mandatory disclosure requirements, but an expansion of the overall content of disclosures beyond the minimal requirements of Regulations S-X and S-K. Giving further impetus to this concern are the sobering statistics on the frequency with which U.S. companies are the subject of securities class actions. One study reports that one of every fourteen companies listed on the New York Stock Exchange has been the subject of a securities fraud suit in the last three years. ${ }^{110}$ Equally alarming is the well-documented pattern of suing companies whenever there is a large drop in the market price of their shares, especially if the companies have recently made public offerings. ${ }^{111}$ And one commentator reports that two major U.S. underwriters are the subject of seventy-three and sixty securities fraud class actions, respectively. ${ }^{112}$ Certainly, nothing is more feared by foreign issuers and market professionals than the thought that they will become grist in U.S. securities class action mills. The above data suggest that this fear is well deserved and is one that should be shared as well by companies and market professionals operating within the United States.

\section{A. Precertification Merit Review of Class Actions}

The frequency of litigation, and particularly representative suit litigation, is now part of the political debate in the United States. One is very much in step with the White House ${ }^{113}$ in questioning the freedom attorneys enjoy to

110. Vincent E. O'Brien, The Class-Action Shakedown Racket, Wall St J A20 col 2-6 (Sept 10, 1991). More startling is that Mr. O'Brien's sample of 330 cases rejects the sage view that it is the small, startup companies that are the subject of securities fraud suits. He finds that nine percent of the defendant companies had been in business for less than five years, whereas $75 \%$ of those sued had been in existence for more than ten years. Moreover, companies with assets greater than $\$ 30$ billion in annual revenues were sued as often as those with $\$ 10$ billion in annual revenues.

111. Michael Selz, Lawsuits Often Follow when Small Firms Go Public, Wall St J B2 col 3-6 (Jan 13, 1992).

112. Janet Cooper Alexander, Do the Merits Matter? A Study of Settlements in Securities Class Actions, 43 Stan L Rev 497, 558 (1991).

113. Allesandra Stanley, The 1992 Campaign: Issues-Tort Reform: Selling Voters on Bush, as Nemesis of Lawyers, NY Times Al col 2-4 (Aug 31, 1992) ("George Bush and Vice President Dan Quayle have begun painting Bill Clinton as a captive of a special interest group, 'sharp lawyers' in 'tasseled loafers' who are ... 'running wild,' terrorizing doctors and even Little League coaches with personalinjury suits, malpractice suits and other kinds of liability cases."); David S. Broder \& Saundra Torry, $A B A$ President Disputes Quayle on Litigation Proposals, Washington Post A1 (Aug 13, 1991) ("ABA President John J. Curtin, Jr. . . . told [Dan Quayle] that the administration was unfairly blaming the 
roam the marketplace with class actions and contingency fee arrangements, mechanisms virtually unknown in other parts of the world. Although suggested ways in which to harness the class action are made below, the benefits of the securities class action must be identified. An earlier discussion examined how each country's laws should proscribe and move resolutely against market fraud. ${ }^{14}$ This feature, above all others, should be the bedrock for the content of any nation's securities laws. Absent honesty in the disclosures that are mandated, the disclosure requirements are meaningless. From a different perspective, one can hypothesize that the amount of foreign investor trading in U.S. securities markets and the prices received on those securities would be less if there were no private enforcement of the securities laws in the United States. The ever-present private sanctions for misleading statements adds further authenticity to the firm's disclosures and enhances the attractiveness of U.S. markets to foreign investors. At the same time, the fear of being the target of such a suit makes U.S. securities markets less attractive to foreign issuers and is very much a part of a U.S. company's decision to raise its capital abroad.

Any rollback in the disclosure demands of Regulations S-X and S-K may well not save the forests from the ravages of lengthy prospecti. A good deal of securities fraud actions are not based on outright lies, but on the misrepresentations that arise from telling only half the truth; that is, a statement is deemed "false" because material information was omitted that was necessary to prevent what was disclosed from creating a false representation.115 For example, a truthful statement about a merger's positive effects on a winery's bottom line does not shield the registrant from suit for failing to disclose that after the merger some of the winery's labels would be bottled in magnum-size and not half-gallon containers. ${ }^{116}$ So understood, there is a very grave risk that without changing the jurisprudence surrounding private actions under the securities laws, there are only limited possibilities of introducing any significant change in the overall mandatory disclosure requirements of Regulations S-X and S-K.

\footnotetext{
legal profession for what Quayle had termed a $\$ 300$ billion-a-year 'self-inflicted competitive disadvantage' in the world economy." This rebuttal was in response to Quayle's "50-point 'civil justice reform' proposal ... [which] includes caps on punitive damages, a 'loser pays' rule for legal costs in certain types of lawsuits and stricter limits on discovery procedures and expert testimony.").

114. See notes $30-38$ and accompanying text.

115. This demand is formally embodied in the filing requirements of the SEC, Rule 408 for the Securities Act and Rule 12b-20 of the Exchange Act, and it is very much a fixture of the jurisprudence of $\S 10$ (b) and Rule 10b-5. See Basic, Inc. v Levinson, 485 US 224 (1988); TSC Industries, Inc. $v$ Northway, Inc. , 426 US 438 (1975); see also Virginia Bankshares, Inc. $v$ Sandberg, - US -, 111 S C 2749 (1991).

116. Jones v National Distillers E Chemical Corp., 484 F Supp 679 (SD NY 1979) (the company argued omission was immaterial because proxy statement accurately forecast overall net income and the forecast took account of switch to magnums). The case was subsequently settled for $\$ 750,000$. Jones v National Distillers $\mathcal{E}$ Chem. Corp., [1979-80 Transfer Binder] Fed Secur L Rptr (CCH) ๆ 97,288 (SD NY 1980).
} 
Most reforms advanced for securities class actions focus on altering the litigants' financial incentives. ${ }^{117}$ These suggestions range from altering the way plaintiff's attorney's fees are determined to various fee-shifting arrangements. Invariably coupled with these suggested changes are settlement review standards designed to involve the class action court more actively in reviewing the proposed settlement. Such proposals are each positive steps toward increasing the overall beneficial effects private litigation can have on reducing the cost of raising capital in U.S. markets. Nevertheless, further reform appears necessary.

One proposal is to involve the courts in securities class actions in a significant way earlier than at the settlement stage. The stakes involved in such cases are too great to limit the judge's involvement at the preliminary stage to determining whether to certify the class. This need is particularly felt in the wake of evidence that certified securities class actions often result in settlements in amounts bearing no relationship to the actions' merits. Early class action cases agreed and embraced a merit review of the action as a prelude to certifying the class. ${ }^{118}$ While this approach was held improper, ${ }^{119}$ amending Rule 23 to bring back the merit review process should be reconsidered. A precertification review of the merits would serve a useful screening function and provide the judge with an early view of meritorious cases that could have other positive effects. ${ }^{120}$ For example, an early familiarity with a meritorious case would prove most useful in any subsequent hearing on the fairness of a proposed settlement where there is substantial concern whether the class members' or lawyers' interests are guiding the settlement terms. ${ }^{121}$

\section{B. Reckless Half-Truths}

In addition to the recommended procedural changes, a substantive change in the law of "half-truths" under antifraud provisions is also needed to accommodate the above revamping of mandatory disclosure requirements. As seen earlier, the content of disclosure is guided not solely by Regulations $\mathrm{S}-\mathrm{X}$ and $\mathrm{S}-\mathrm{K}$, but also by the jurisprudence of implied causes of action, which compel disclosures necessary to avoid a materially misleading representation. Without changing the substance of the law of half-truths, no significant gains

117. See, for example, John Macey \& Geoffrey Miller, The Plaintiff's Attorney's Role in Class Action and Derivative Litigation: Economic Analysis and Recommendations for Reform, $58 \mathrm{U}$ Chi L Rev 1 (1991); John C. Coffee, Jr., The Regulation of Entrepreneurial Litigation: Balancing Fairness and Efficiency in the Large Class Action, 54 U Chi L Rev 877 (1987); John C. Coffee, Jr., The Unfaithful Champion: The Plaintiff as Monitor in Shareholder Litigation, 48 L \& Contemp Probs 5 (Summer 1985).

118. Doglow $v$ Anderson, 43 FRD 472, 501 (ED NY 1968).

119. Eisen v Carlisle E Jacquelin, 417 US 2140 (1974).

120. See Colleen M. Martin, Note, Merit-Based Class Action Certification: Old Wine in a New Bottle, 78 Va L. Rev 967, 1023-36 (1992).

121. See Allegheny Corp. $v$ Kirby, 313 F2d 327, 334-45 (2d Cir 1964) (Friendly dissenting) ("Once a settlement is agreed, the attorneys for the plaintiff stockholders link arms with their former adversaries to defend the joint handiwork."). 
are likely to occur in overall disclosure requirements because issuers will feel obligated to disclose more than the mandatory disclosure regulations require.

One possible approach is to alter the materiality standard so that information is material only if it would likely change the price at which investors would purchase or sell a security, or more dramatically cause the investors not to purchase or sell at all. ${ }^{22}$ This change is ill-advised for two reasons, however. First, it is not likely to lead to the effects desired; plaintiff's counsel may well be able to locate experts who can demonstrate materiality even under the more demanding standard and establish a causal relationship between the omission or misstatement and the damages to be recovered. In cases where the alleged fraud was upon purchasing or selling shares in the secondary trading market, the plaintiff must prove that the omission or misstatement affected the price at which the security traded.123 A second concern with redefining materiality is it casts aside the certainty securities practitioners can achieve by accessing the hundreds of decisions courts and the SEC have handed down over the years on the meaning of materiality. Abandoning this standard would increase the amount of uncertainty in materiality determinations, just the opposite result that is sought by the reform.

A far more fruitful and positive approach to the matter of half-truths is to tighten the scienter requirement for omitted information. Where the information omitted from an SEC filing is not required by Regulations S-X or $\mathrm{S}-\mathrm{K}$, it would appear advisable to impose responsibility only if some element of purpose or knowledge accompanied the affirmative decision to omit the information. Minimally, this approach would require the rejection of the recklessness standard embraced by the circuit courts of appeal for Rule 10b-5 actions. ${ }^{124}$ The standard suggested here is, however, only slightly more demanding than the contemporary one under which scienter is established if the defendant were aware of the true state of affairs and appreciated the propensity of the information to mislead. ${ }^{125}$ What appears most appropriate is not simply a conscious omission of the information-the information was known or must have been known to the preparers of the filed statements-but also that the information was knowingly omitted from the filing or announcement in question, not inadvertently excluded. This change would overcome the pernicious aspects of the contemporary recklessness standard

122. Currently, a statement or omission is material without "proof of a substantial likelihood that disclosure of the omitted fact would have caused the reasonable investor to change his vote" or investment decision. TSC Industries, Inc. v Northway, Inc., 426 US 438, 449 (1975).

123. See, for example, Green v Occidental Petroleum Corp., 541 F2d 1335 (9th Cir 1976) (Sneed concurring). More generally, see Braddord Cornell \& $\mathbf{R}$. Gregory Morgan, Using Finance Theory to Measure Damages in Fraud on the Market Cases, 37 UCLA L Rev 883 (1990).

124. See Paul S. Milich, Securities Fraud under Section 10(b) and Rule 10b-5: Scienter, Recklessness, and the Good Faith Defense, $11 \mathrm{~J}$ Corp $\mathrm{L} 179$ (1986) (reviewing the many articulations of recklessness under the antifraud provision). Among the more liberal constructions of recklessness is that of the First Circuit as being "carelessness approaching indifference." Hoffman v Eastbrook $\mathcal{G}$ Co., 587 F2d 509, 516 (1st Cir 1978).

125. See, for example, SEC v Falstaff Brewing Co., 629 F2d 62, 76 (DC Cir 1980). 
because the proposed standard would not impose liability for omissions indifferently committed.

\section{Rethinking Section 11 Liability Under the Securities Act}

A final area worthy of reconsideration is the scope of liability under section 11 of the Securities Act for material omissions or misstatements in registration statements. Under section 11, issuers are liable without fault, whereas directors, underwriters, and those who sign the registration statement are liable if they cannot establish a "due diligence" defense. ${ }^{26}$ One of the distinct costs to issuers or underwriters contemplating a public offering of securities in the United States is their respective exposure to section 11 liability. The competitive disadvantages of U.S. public offerings brought about by section 11 appear not simply in the frequency of securities class actions following the collapse of a public offering's price, ${ }^{127}$ but also in the absence of equally demanding standards for liability in rival foreign markets.

The impact of liability under section 11 can be overstated or misunderstood, however. One of the most famous securities cases, Escott $v$. BarChris Construction Co., ${ }^{128}$ held that senior officers, outside directors, underwriters, and an outside auditor all failed to satisfy their due diligence defenses. By way of illustration, one outside director relied upon representations by management that the registration statement was complete, while his fellow director was faulted for, among other lapses, failing to examine original documents bearing on whether projects listed as being among the backlog of projects were in fact firm orders. The underwriters were similarly faulted for not verifying data supplied to them by management. The historical justification for imposing such burdensome demands on these parties is the recognition that when an issuer is involved in a public offering of its securities and its position conflicts with that of its offerees, issuers have natural incentives to shade the truth. For this reason, intervention into the disclosure process by a neutral referee has a good deal of appeal and thus seems to be the overall mission of the due diligence requirements of section 11. This observation is particularly true for underwriters; among the nonexperts to whom section 11 liability extends, underwriters enjoy the greatest independence and financial sophistication, best equipping them to discharge the public interest under the threat of section 11 liability.

126. This requires proof that the individual "had, after reasonable investigation, reasonable ground to believe and did believe" the registration statement was free of material omissions and misstatements when it became effective. Securities Act of 1933, ch 38, tit I $\$ 1$ I (b)(3)(A), I5 USC $\S 77 \mathrm{k}(\mathrm{b})(3)(\mathrm{A})$ (1933). As to any portion of the registration statement prepared on the authority of an expert, nonexperts satisfy their defense if they "had no reasonable ground to believe and did not believe" the registration statement contained a material misrepresentation. Securities Act Amendments of 1934, ch 404, tit II $\S 206(\mathrm{~b}), 15$ USC $\$ 77 \mathrm{k}(\mathrm{b})(3)(\mathrm{A})$ (1934); see also Virginia Bankshares, Inc. v Sandberg, 111 S Ct 2749 (1991).

127. Selz, Wall St J at B2 col 3-6 (cited in note 111).

128. 283 F Supp 643 (SD NY 1968). 
However, the pressures of competition, including the advent of the integrated disclosure mechanisms whereby large seasoned corporations can quickly "go to market," have strained the traditional bond between issuers and underwriters. ${ }^{129}$ Issuers that qualify to use Forms S-2 or S-3 may go to market more rapidly because they can incorporate by reference information previously filed to satisfy their continuous reporting obligations under the Exchange Act. The resulting process shortens the time the underwriter has to fulfill its due diligence investigations, and the resulting competition for fees further limits the resources underwriters commit to this part of their undertaking. ${ }^{130} \mathrm{~A}$-further question is whether underwriter liability is necessary in light of the substantial reputational interest underwriters have at stake, which is certainly the case when they serve as lead underwriters. ${ }^{131}$ Underwriters are the quintessential repeat player and, as such, suffer great reputational injury when associated with offerings of securities whose prices collapse soon after the offering, whether or not the collapse is linked to a misleading prospectus. Thus, underwriters may carry out reasonable investigation even in the absence of statutory liability. Such considerations have caused Professor Langevoort to recommend removing underwriters from section 11 liability, believing this would allow securities offering practices to evolve to less costly, more efficient arrangements between issuers and underwriters. ${ }^{132}$

Professor Langevoort's suggestions are intriguing, especially in light of the increasing international competition among underwriters and markets. Nevertheless, the exact reform desirable for section 11 liability quite probably is an empirical question. With this approach in mind, the following suggestions sketch areas worthy of investigation. The first is the desirability of continuing to hold an issuer absolutely liable if its registration statement contains a material misrepresentation. The concern here is not exclusively for issuers, although it is hard to deny this provision does increase their offering costs, but, more significantly, what effect the issuer's greater exposure has on the likelihood that others, particularly underwriters, will be implicated in a section 11 action. It appears to be an easy proposition that a plaintiff attorney's marginal costs are not increased significantly by adding to a suit against an absolutely liable issuer (assuming the registration statement contained a material misrepresentation) causes of action against other

129. See Samuel L. Hayes, A. Michael Spence \& Donald Von Praag Marks, Competition in the Investment Banking Industry (Harvard U Press, 1983).

130. See generally Edward F. Greene, Determining the Responsibility of Underwriters Distributing Securities within Integrated Disclosure System, 56 Notre Dame L Rev 755, 787-90 (1981).

131. See Michael P. Dooley, The Effects of Civil Liability on Investment Banking and the New Issues Market, 58 Va L Rev 776 (1972). However, there is at least one school of thought that argues the systematic underpricing of securities offered in an IPO reflects compensation demanded by underwriters for the negligence liability risks they incur. Seha M. Tinic, Anatomy of Initial Public Offerings of Common Stock, 43 J Finance 789 (1988).

132. Langevoort, $98 \mathrm{Harv} \mathrm{L} \mathrm{Rev}$ at 776-78 (cited in note 109). He suggests the resulting void, if any, in investigation of the registration statement could be filled in several ways, such as by tightening up the demands on senior management officials or outside accountants. 
defendants, especially if those defendants have considerable resources. Assuming a solvent issuer, plaintiff's counsel may currently conclude that a reasonable settlement is more likely to be arrived at by implicating an issuer and the forty-nine members of the underwriting syndicate rather than by proceeding solely against the issuer. This is especially so if the settlement amount proposed is not significant when divided fifty ways but would be catastrophic if not divided at all.

At the same time, it is worth considering how great a cost is added to the underwriting and offering process by the due diligence investigation required by underwriters and others. On this point, it should be observed that courts today appear more sympathetic to the problems faced by underwriters and others in discharging their section 11 liability. Several recent decisions have granted underwriters' and outside directors' motions for summary judgment where there was evidence of their review of management-prepared reports and selected outside sources in discharging their due diligence investigation. ${ }^{133}$

In sum, there needs to be a thorough analysis of the costs and benefits of section 11 liability for issuers as well as those subject to the due diligence obligations of section 11 , including a close review of who actually discharges the investigation demanded by section 11 . If these are issuer-related investigations, such that it is the issuer's counsel and attorneys that perform much of the investigation relied upon by underwriters, there are substantial additional costs beyond those that the underwriter would have undertaken merely to apprise itself whether to become involved in the offering and the appropriate price for the offering. Investigations that transcend these concerns add costs beyond those necessary for the underwriter to inform itself reasonably as to the advisability of its participation and the pricing of the offering. Such additional costs are the true costs of section 11 liability. To the extent the investigations eclipse similar investigations conducted for foreign offerings, they place U.S. offerings at a competitive disadvantage if the resulting reduction in the costs of capital is not commensurate with the investigation costs. The remaining focus is whether the exposure of underwriters and others to the costs of litigation is enhanced by the issuer being deprived of a due diligence defense under section 11 . Resolving both questions can tell us much about the competitiveness of U.S. laws for public offerings versus those of rival nations.

\section{VIII}

\section{CONCLUSION}

Technological developments have exposed the United States to international regulatory competition that will not abate. This article urges the

133. See, for example, Weinberger $v$ Jackson, [1990 Transfer Binder] Fed Secur L Rptr (CCH) I 95,693 (ND Ca 1990); Laven v Flanagan, 695 F Supp 800 (D NJ 1988); Competitive Associates $v$ International Health Sciences, [1975 Transfer Binder] Fed Secur L Rptr (CCH) 9 94,966 (SD NY 1975); In re Avant-Guarde Computing, Inc. Litigation, 1989 WL 103625 (D NJ 1989). 
United States to meet that challenge and sets forth principles to meet it without resort to a "race to the bottom." First, the article illustrated that regulatory competition is healthy, provided the points in competition do not afford opportunities for managerial opportunism. The United States needs to continue its lead in bringing about mutual understanding in disclosure requirements that curb both managerial opportunism and the manipulation of reports. As was seen, this does not require harmony in disclosure standards; differences can well exist among countries over the depth and details of their disclosures. There is a grave need, however, to improve international disclosure standards in those areas, such as reserve accounting, where management can create the false appearance of economic activity.

The article also showed that the United States should avoid those accommodations that have the perverse effect of driving securities transactions to foreign markets. Relieving multinational transactions of U.S. regulatory burdens because of their de minimis effects in the United States makes sense only when domestic investor interests are better served by relaxing those regulatory protections. In other instances, there is a real need to reexamine the utility of the United States' marginally more demanding requirements. The case in point examined earlier is the overly broad demands of U.S. distribution rules.

The United States must also begin the wholesale review of the content of both its disclosure requirements and antifraud rules. As developed above, the former cannot be relaxed effectively unless the demands of the express and implied causes of action under the securities laws are effectively narrowed. If this can be done, then Regulations S-X and S-K can, as suggested here, be reviewed to identify those areas where mandatory disclosure requirements are necessary in light of the otherwise weak incentives managers have to disclose financially significant information.

In sum, U.S. securities laws are now at their zenith in terms of their demands and protection of investors. They provide a pure and pristine image of the wonderful protective benefits that can arise through government regulation. Those laws are enforced aggressively by public and private enforcement actions, but most importantly through their in terrorem effects. But internationalization most assuredly commits our present regulatory structure to the museum of days gone past; it is now time to station our markets and their participants for the realities of the twenty-first century by engaging in a wholesale review and deregulation of U.S. securities laws. The principles developed above provide a framework within which such change can occur so as to preserve the protection investors currently enjoy under the securities laws. 